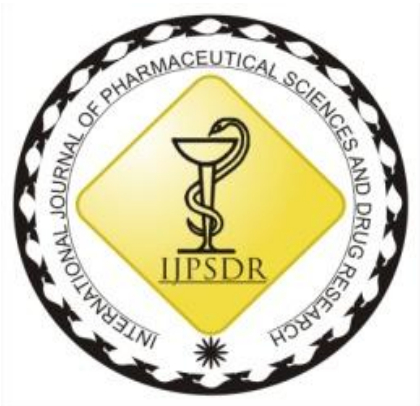

ISSN: 0975-248X

RESEARCH ARTICLE CODEN (USA): IJPSPP $(\mathrm{cc})$ EY-NG-SA

\title{
Formulation and Evaluation of Controlled Release Maintenance Dose Loaded Niosomes of Anti-Hypertensive Drug
}

\author{
Chandani Makvana*, Satyajit Sahoo \\ Faculty of Pharmacy, C. U. Shah University, Surendranagar-Ahmedabad highway, Near Kothariya village, Dist. \\ Surendranagar, Wadhwan-363030, Gujarat, India
}

Copyright (C) 2019 Chandani Makvana et al. This is an open access article distributed under the terms of the Creative Commons AttributionNonCommercial-ShareAlike 4.0 International License which allows others to remix, tweak, and build upon the work non-commercially, as long as the author is credited and the new creations are licensed under the identical terms.

\begin{abstract}
The present study was aimed to formulate, comparatively evaluate and optimize multiple lipid drug carriers of valsartan for oral controlled release to overcome the problems associated with the drug such as bioavailability, to reduce the dosage regimen, half life and to determine the appropriateness of niosomal formulation as a drug carrier. Ether injection method was chosen for the formulation of physically and chemically stable niosomes of valsartan. The formulation and process parameters were optimized by manufacturing placebo niosomes. Than drug loaded niosome was prepared by varying the concentration of span 60 . The prepared nine formulations were evaluated for various parameters. Placebo niosomes were evaluated for appearance, odour, texture, creaming volume, $\mathrm{pH}$ and changes after 15 days. The medicated nine formulations were evaluated for organoleptic properties (appearance/color, odour), pH, total drug content, entrapment efficiency, mean particle size and polydispersibility index, zeta potential and In-vitro drug release. All formulations were off-white in color, odourless, and fluid in nature. It was stable and did not show sedimentation. The $\mathrm{pH}$ was found to be in the range of 4.6-5.4. Drug content was found in the range of 89.13 to 99.52 . The Entrapment efficiency was found in range of 79.05 to 98.24 . The mean vesicle size of drug loaded niosomes of the different batches ranged between 2.52-3.42 $\mu \mathrm{m}$. The polydispersvity index was in the range of 0.325 to 0.420 which indicates a narrow vesicle size distribution. The values of zeta potential were in the range of $-20.29 \mathrm{mV}$ to $-30.55 \mathrm{mV}$ which indicates that niosome had sufficient charge and mobility to inhibit aggregation of vesicles. All the nine formulations shows constant drug release in controlled manner up to 24 h. Formulation V7 was considered to be the best formulation as the $\%$ drug content ( $99.52 \pm 0.97$ ), $\%$ entrapment efficiency $(98.24 \pm 1.50)$ and $\%$ drug release at the end of $24^{\text {th }} \mathrm{h}(98.55)$ were high for V7. The optimized formulation V7 showed higher degree of correlation coefficient $\left(\mathrm{r}^{2}\right) 0.9805$ which indicates process of constant drug release from dosage form. The present study concludes that the prepared niosome is a convenient and efficiency carrier for the delivery of antihypertensive drug. Besides this, it provided controlled delivery of drug.
\end{abstract}

Keywords: Niosomes, Valsartan, Ether injection technique, Vesicular size, Controlled drug delivery.

DOI: 10.25004/IJPSDR.2019.110605

Int. J. Pharm. Sci. Drug Res. 2019; 11(6): 305-317

\footnotetext{
*Corresponding author: Ms. Chandani Makvana

Address: Faculty of Pharmacy, C. U. Shah University, Surendranagar-Ahmedabad highway, Near Kothariya village, Dist. Surendranagar, Wadhwan363030, Gujarat, India

E-mail $\bowtie$ : chandani.makvana1991@gmail.com

Relevant conflicts of interest/financial disclosures: The authors declare that the research was conducted in the absence of any commercial or financial relationships that could be construed as a potential conflict of interest.

Received: 13 August, 2019; Revised: 19 October, 2019; Accepted: 30 October, 2019; Published: 30 November, 2019
} 


\section{INTRODUCTION}

Niosomes are non-ionic surfactant of the alkyl or dialkyl polyglycerol ether class and cholesterol with subsequent hydration in aqueous media. These are lamellar structures that are microscopic in size. Structurally niosomes are bilayered in nature. On the basis of preparation methods used, niosomes may be unilayer or multilayer. [1-2] Depending on various factors such as stability and cost, the niosomes are considered ideal when compared with liposomes. For various routes such as topical, ophthalmic and parenteral niosomes prove to be a potential and possible drug delivery mechanism. [3] It was prepared by the method of ether injection method, handshaking method (thin film hydration technique), sonication, microfluidization, multiple membrane extrusion method, reverse phase evaporation technique, transmembrane $\mathrm{pH}$ gradient (inside acidic) drug uptake process (remote loading) and the "Bubble" method. [4-8] Various factors affecting niosomal formulations are type of surfactant, drug and amount, charge and cholesterol content, osmotic stress due to resistance and constitution of membrane. [9-12]

The main aim of this project is to study about niosome which is emerging as a potential drug carrier, as a new drug delivery for the antihypertensive drug Valsartan. Valsartan a widely prescribed anti hypertensive drug belongs to class II under BCS classification and exhibit low and variable bioavailability due to its aqueous solubility and it has a shorter half life $(6 \mathrm{~h}) .{ }^{[13]}$ The oral bioavailability of Valsartan was reported to $23 \%$. [14] Due to this it require frequent dosing to maintain the therapeutic blood level of the drug for long term treatment. Therefore, the objective behind the study is to sustain the action by incorporating the maintenance dose of drug into the vesicular carriers. [15]

\section{MATERIALS AND METHODS}

\section{Chemicals and reagents}

Valsartan was obtained as gift sample from Torrent research centre, Ahmedabad, India. Sorbitan monostearate (Span 60) and Diethyl ether were purchased from Merck limited, Mumbai, India. Cholesterol was purchased from Loba chemie, Boisar, India. All the other reagents and chemicals were of analytical grade.

Instruments

Electronic Weighing Balance (Mettlet Toledo, XP205, B047091022), Magnetic stirrer (Remi, 2 MLH), Sonicator (Life care instruments pvt. ltd.), UV Spectrophotometer (Lab India, UV3092, 20-1950-21-0004), FTIR Spectrophotometer (Bruker, Alpha, 200430), Differential Scanning Colorimeter (DSC) (Shimadzu, DSC 60), Hot air oven (Equichem, 1109/07) and pH meter (Eutech, pH2700, 739092) were used in present work.

\section{Preformulation study of drug}

Pre-formulation investigations are to provide information on physicochemical and biopharmaceutical study properties of drug molecule, non-drug substance and materials used for packaging as well as compressibility

\section{Characterization of Pure drug}

Valsartan was obtained as a gift sample from Torrent research centre, Ahmedabad and were subjected to following characterization tests.

\section{Determination of $\lambda_{\max }$ by UV spectroscopy}

Using Methanol, the absorption maxima of Valsartan was obtained. A range of solutions $(2-10 \mu \mathrm{g} / \mathrm{ml})$ was scanned using UV spectrophotometer.

\section{Melting point determination}

Melting point of Valsartan was determined using capillary tube method. Observed value was compared with the reported value.

\section{FTIR spectroscopy}

The IR spectrum of Valsartan was recorded using Fourier transform infrared spectrophotometer with diffuse reflectance principle by $\mathrm{KBr}$ press pellet method.

\section{Loss on Drying}

A sample of $0.1 \mathrm{~g}$ of Valsartan was weighed individually in a vessel. The sample containing vessel was then placed in an hot air oven at $100^{\circ} \mathrm{C}$ for $4 \mathrm{~h}$. The sample was cooled in a desiccator and weighed. [16]

\section{DSC study}

The DSC thermogram of Valsartan was recorded using Differential scanning calorimeter. Approximately 2 to 5 $\mathrm{mg}$ of sample will be heated in a closed pierced aluminum pan from $30^{\circ} \mathrm{C}$ to $180^{\circ} \mathrm{C}$ at a heating rate of $5^{\circ} \mathrm{C} / \mathrm{min}$ under a stream of nitrogen at a flow rate of 50 $\mathrm{ml} / \mathrm{min}$.

\section{Equilibrium solubility study}

The shake flask method was used to determine saturation solubility of Valsartan in different solvent (i.e. Methanol, $0.1 \mathrm{~N} \mathrm{HCl} \mathrm{pH} \mathrm{1.2,} \mathrm{Phosphate} \mathrm{buffer} \mathrm{pH}$ 6.8 and Phosphate buffer $\mathrm{pH} 7.2$ ).

$\%$ Purity

For \% purity, $100 \mathrm{mg}$ of Valsartan were individually weighed and transferred to a $100 \mathrm{ml}$ of volumetric flask. Then the volume was made up to $100 \mathrm{ml}$ mark with methanol. The flask was kept on a sonicator individually for $5 \mathrm{~min}$. Solution was then filtered using a whatman filter paper. Then aliquot $10 \mathrm{ml}$ from the filtered solution and dilute it up to $100 \mathrm{ml}$ using methanol. Then absorbance of the resulting solution was measured at the $\lambda \max 250 \mathrm{~nm}$ for Valsartan using UV-Visible double beam spectrophotometer against methanol as blank. The linearity equation obtained from calibration curve was used for estimation of purity of Valsartan. [16]

\section{Powder characterization (physical properties)}

Valsartan was characterized by Angle of repose, Bulk density, Tapped density, Carr's index and Hausner's ratio. [16-18]

\section{Drug excipients compatibility studies}

The drug Valsartan and excipients must be compatible with one another to produce a product i.e. stable, efficacious, attractive, easy to administer and safe. The 
compatibility study of the drugs: excipients in physical mixture (1:1) were checked out using the shimadzu FTIR spectrophotometer by KBr press pellet method. [19] The FTIR spectra of pure drugs and with the excipients are shown in Fig. 3 and Fig. 4.

Analytical method development and validation

Analytical measurement of Valsartan in Methanol by UV spectrophotometry was validated separately as per $\mathrm{ICH}$ guideline, Q2(R1). The UV spectrophotometric method was validated for the quantification of Valsartan in samples. Intraday and Interday precision and accuracy were determined by analysis of five concentrations. The overall precision of the method was expressed as relative standard deviation (RSD) and the accuracy of the method was expressed in terms of relative error. [20]

Preparation of standard curve of Valsartan in Methanol at $250 \mathrm{~nm}$

Preparation of standard stock solution $(1000 \mu \mathrm{g} / \mathrm{ml})$

Accurately weighed $100 \mathrm{mg}$ of Valsartan was dissolved in $100 \mathrm{ml}$ of Methanol to get a concentration $1000 \mu \mathrm{g} / \mathrm{ml}$. This course of action was then used for arranging working standard plan.

Preparation of working standard solution $(100 \mu \mathrm{g} / \mathrm{ml})$ $10 \mathrm{ml}$ standard stock solution of Valsartan was transferred to a $100 \mathrm{ml}$ volumetric flask and volume was adjusted to $100 \mathrm{ml}$ with Methanol to get a concentration of $100 \mu \mathrm{g} / \mathrm{ml}$.

Preparation of dilutions for calibration curve

With appropriate dilution of working standard solution $5,10,15,20,25,30,35$ and $40 \mu \mathrm{g} / \mathrm{ml}$ concentration of Valsartan was obtained. The absorbance of prepared solutions of Valsartan in Methanol was measured at wavelength maximum $250 \mathrm{~nm}$ using Shimadzu UV1800 spectrophotometer against Methanol as blank. The experiment was performed in triplicate and based on average absorbance; the equation for the best line was generated. The results of standard curve preparation are shown in Table 6 and Fig. 5.

Validation of analytical method of Valsartan in Methanol

Analytical measurement of Valsartan in Methanol by UV spectrophotometry was validated as per ICH guideline, Q2AR1.

Linearity and range

Linearity is expressed in terms of correlation coefficient of linear regression analysis. The linearity response was determined by analyzing 8 independent levels of calibration curve in the range of $5-40 \mu \mathrm{g} / \mathrm{ml}$. Plot the calibration curve of absorbance vs concentration and determines correlation coefficient and regression line equations for Valsartan.

Accuracy preparation of sample solution

The accuracy study was determined by standard addition method. $100 \mathrm{mg}$ of Valsartan was weighed and transferred into a $100 \mathrm{ml}$ of volumetric flask, dissolved and diluted up to mark with Methanol. Pipette out $10 \mathrm{ml}$ of the above solution in $100 \mathrm{ml}$ volumetric flask and diluted to mark with Methanol to get $100 \mu \mathrm{g} / \mathrm{ml}$ solution of Valsartan, from that $10 \mu \mathrm{g} / \mathrm{ml}$ of solution was prepared. To one $\mathrm{ml}$ of the above solution, increasing aliquots of standard solution $(5,10$ and $15 \mu \mathrm{g} / \mathrm{ml}$ of Valsartan) was added and diluted to 10 $\mathrm{ml}$ with Methanol. Absorbance of solution was measured at selected wavelength. The amount of Valsartan was calculated at each level and \% recoveries were computed.

\section{Precision}

Repeatability: The absorbance of same concentration was measured three times and RSD was calculated.

Intraday Precision: Solutions containing 5-40 $\mathrm{gg} / \mathrm{ml}$ of Valsartan was analyzed three times on the same day and \% RSD was calculated.

Interday Precision: Solutions containing 5-40 $\mathrm{gg} / \mathrm{ml}$ of Valsartan was analyzed three times on the different $3 \mathrm{~d}$ and \% RSD was calculated. It is a measure of either the degree of reproducibility or repeatability of the analytical method.

\section{LOD}

The limit of detection (LOD) is the lowest amount of analyte in a sample that can be detected, but not necessarily quantified, under standard experimental condition. LOD will be calculated using the following formulae:

$$
\mathrm{LOD}=3.3 \sigma / \mathrm{S}
$$

Where $\sigma$ is Standard deviation of the response and $S$ is slope of the calibration curve.

\section{LOQ}

The limit of quantification (LOQ) is the lowest amount of analyte in a sample that can be determined with acceptable precision and accuracy under standard experimental condition. LOQ were calculated using the following formulae:

\section{$\mathrm{LOQ}=10 \sigma / \mathrm{S}$}

Where $\sigma$ is Standard deviation of the response and $S$ is slope of the calibration curve.

\section{Formulation development of Niosome}

Quality Target Product Profile for the finished dosage form

Based on properties of drug substance, intended patient population and literature studies Quality target product profile (QTPP) was defined for finished dosage form Niosome. [21]

Critical quality attributes (CQAs) of finished dosage form based on QTPP

Based on severity of harm to a patient (safety and efficacy) resulting from failure to meet that quality attribute of the finished dosage form critical quality attributes (CQAs) was defined. [22]

Dose calculation for loading and maintenance dose of Valsartan

Oral dose (Xo): $80 \mathrm{mg}$

Dosing interval $(\tau): 24 \mathrm{~h}$

Elimination half life $\left(\mathrm{t}_{1 / 2}\right): 6 \mathrm{~h}$

Elimination rate constant $(\mathrm{Ke})=\frac{0.693}{\mathrm{t}_{1 / 2}}=\frac{0.693}{6}=0.1155$ 


\begin{tabular}{|c|c|}
\hline QTPP Element & Target \\
\hline Dosage form & Niosomes \\
\hline Dosage design & Sustained release \\
\hline Route of administration & Oral \\
\hline Dosage strength & 51.14 mg Valsartan (maintenance dose) \\
\hline Stability & At least 24 mo shelf life at room temperature \\
\hline $\begin{array}{l}\text { Drug product quality } \\
\text { attributes }\end{array}$ & $\begin{array}{l}\text { Organoleptic properties, } \mathrm{pH} \text {, total drug content, } \\
\text { Entrapment efficiency, Mean particle size, } \\
\text { Polydispersibility index, Zeta potential and In-Vitro } \\
\text { drug release }\end{array}$ \\
\hline Container closure system & Suitable container closure system \\
\hline
\end{tabular}

Justification

Higher stability, Low cost and Sustained effect

Hypertension is a widespread condition of the high systemic arterial pressure and it is an important factor for the extension of cardiovascular diseases. Valsartan loaded niosomes for sustained release that will help to maintain therapeutic concentration of drug and also reduces the frequency of dosing and give better patient compliance.

Better patient compliance

To maintain therapeutic concentration of drug for prolonged period of time

Maintain Quality, safety and efficacy throughout product life cycle.

Meeting the same compendia or other applicable (quality) standard

Needed to achieve the target shelf-life and to ensure finished dosage form integrity during shipping

QTPP: Quality Target Product profile

Table 2: Critical quality attributes (CQAs) of Niosomes

\begin{tabular}{|c|c|c|c|}
\hline $\begin{array}{l}\text { Quality attributes of the finished } \\
\text { dosage form }\end{array}$ & Target & $\begin{array}{l}\text { Is it } \\
\text { CQA? }\end{array}$ & Justification \\
\hline $\begin{array}{l}\text { Organoleptic properties } \quad \text { (Colour, } \\
\text { Odour) }\end{array}$ & Should be acceptable to patient & No & $\begin{array}{l}\text { Color, Odour and appearance are not directly linked to } \\
\text { safety and efficacy. Therefore, they are not critical. The } \\
\text { target is set to ensure patient acceptability. }\end{array}$ \\
\hline $\mathrm{pH}$ & $\begin{array}{l}\text { Should meet the relevant } \\
\text { pharmacopoeia }\end{array}$ & No & $\begin{array}{l}\mathrm{pH} \text { is not directly linked to safety and efficacy. Therefore, } \\
\text { they are not critical. }\end{array}$ \\
\hline Total drug content & $100.0 \%$ of label claim & Yes & $\begin{array}{l}\text { Drug content variability should affect safety and efficacy. } \\
\text { Process variables may affect the drug content of the } \\
\text { finished dosage form. Hence, it is critical parameter. }\end{array}$ \\
\hline Entrapment efficiency & $\begin{array}{l}\text { Should have maximum drug } \\
\text { entrapment }\end{array}$ & Yes & $\begin{array}{l}\text { Entrapment efficiency should have impact on drug release. } \\
\text { Hence, it is critical parameter. }\end{array}$ \\
\hline $\begin{array}{l}\text { Mean particle size, Polydispersibility } \\
\text { index }\end{array}$ & $\begin{array}{l}\text { Should have narrow vesicle size } \\
\text { distribution }\end{array}$ & Yes & $\begin{array}{l}\text { Particle size affect the uniform distribution of API and } \\
\text { drug release. Hence, it is critical parameter. }\end{array}$ \\
\hline Zeta potential & Should have sufficient charge & Yes & $\begin{array}{l}\text { Zeta potential affect the mobility to inhibit aggregation of } \\
\text { niosomes. Hence, it is critical parameter. }\end{array}$ \\
\hline In-Vitro drug release & $\begin{array}{l}\text { Should have maximum drug } \\
\text { release at } 24^{\text {th }} \mathrm{h}\end{array}$ & Yes & $\begin{array}{l}\text { Failure to meet the In-Vitro drug release specification can } \\
\text { impact bioavailability. Both formulation and process } \\
\text { variables affect the dissolution profile. Hence, it is critical } \\
\text { parameter. }\end{array}$ \\
\hline
\end{tabular}

CQA: Critical quality attributes

$\mathrm{D}_{\mathrm{L}}=\frac{\text { Css } \cdot \mathrm{Vd}}{\mathrm{F}}$

But, Css $=\underline{\text { F.Xo }}$

Ke.Vd. т

Thus, DL $=\underline{\text { F.Xo. Vd }}$

Ke.Vd.t.F

$\mathrm{DL}=\underline{\mathrm{Xo}}$

Ke. $\tau$

$\mathrm{DL}=\underline{80}$

0.1155 .24

$\mathrm{D}_{\mathrm{L}}=28.86 \mathrm{mg}$

$\mathrm{D}_{\mathrm{T}}=\mathrm{D}_{\mathrm{L}}\left(1+\frac{\left.0.693{ }^{*} \tau\right)}{\mathrm{t}_{1 / 2}}\right.$

$\mathrm{D}_{\mathrm{T}}=28.86\left(1+\frac{0.693 * 24)}{6}\right.$

$\mathrm{D}_{\mathrm{T}}=28.86\left(1+\frac{16.632)}{6}\right.$

$\mathrm{D}_{\mathrm{T}}=28.86 \times 3.772$

$\mathrm{D}_{\mathrm{T}}=79.99 \mathrm{mg}=80.00 \mathrm{mg}$

$\mathrm{D}_{\mathrm{T}}=\mathrm{D}_{\mathrm{L}}+\mathrm{D}_{\mathrm{M}}$

$80.00=28.86+D_{M}$
$\mathrm{D}_{\mathrm{M}}=\mathrm{D}_{\mathrm{T}-} \mathrm{D}_{\mathrm{L}}$

$D_{M}=\mathbf{8 0 . 0 0 - 2 8 . 8 6}=\mathbf{5 1 . 1 4} \mathrm{mg}$

Where,

$\mathrm{D}_{\mathrm{L}}=$ Loading dose

$\mathrm{D}_{\mathrm{M}}=$ Maintenance dose

$\mathrm{D}_{\mathrm{T}}=$ Total dose

Css= Steady state concentration

$\tau=$ Time for intended release

$\mathrm{t}_{1 / 2}=$ Biological half life

$\mathrm{Vd}=$ Volume of distribution

Preparation of Niosomes by Ether injection method

Preparation of Placebo Niosomes

Description of manufacturing process

The various concentration ranges of non ionic surfactant Span 60 and Cholesterol were weighted accurately and dissolved in $10 \mathrm{ml}$ of ether in a small beaker. In another beaker $10 \mathrm{ml}$ phosphate buffer $\mathrm{pH}$ 6.8 was taken. Then the dissolved surfactant/lipid solution was taken into a syringe and injected slowly at a different rate of addition, via a 24 gauge needle in phosphate buffer $\mathrm{pH} 6.8$ which was magnetically 
stirred at different RPM continuously and maintained at different temperature for different time. As the lipid solution was injected slowly into the aqueous phase, vaporization of ether leads to the formation of niosomes.

Preliminary characterization of placebo niosomes Organoleptic properties

The placebo niosomes were evaluated for colour, odour, appearance and texture.

\section{Creaming volume}

The placebo niosomes were kept undisturbed for $24 \mathrm{~h}$ in measuring cylinder and evaluated for separation, creaming and redispersibility.

$\mathrm{pH}$

The $\mathrm{pH}$ of placebo niosomes was checked with digital $\mathrm{pH}$ meter.

\section{Changes after $15 \mathrm{~d}$}

The placebo niosomes were kept undisturbed for two weeks and were observed for any changes in the formulations.

Effect of Critical formulation parameters and processing parameters on formation of niosomes

After optimizing the type of span and cholesterol in the preparation of Niosomes; the processing parameters such as rate of addition, stirring speed, stirring time and stirring temperature were optimized.

\section{Type of non-ionic surfactant}

Different type (grade) of Span was used for formulation of niosomes. Optimize the concentration in niosome using maximum drug entrapment.

\section{Surfactant: Cholesterol ratio}

The surfactant cholesterol ratio is very important to optimize because the cholesterol acts as stabilizer and itself is lipophilic in nature so increased concentration of cholesterol may cause reduction in drug entrapment. The optimum concentration is needed otherwise vesicle stability may decrease. Optimize the ratio by niosomes having maximum drug entrapment.

\section{Effect of Rate of addition}

The ether solution was injected rapidly as well as dropwise into aqueous phase to study its effect on vesicle size. Optimize the rate of addition by distribution size of niosomes.

\section{Effect of Stirring speed and time}

The dispersion was stirred for varied speed and time. Optimize the rate of addition by distribution size of niosomes.

\section{Effect of Stirring temperature}

The dispersion was stirred at different temperature. Optimize the rate of addition by distribution size of niosomes.

Optimization \& Preparation of drug loaded niosomes (Medicated Niosomes)

After optimization of formulation and process parameters medicated niosomes was prepared. The various concentration ranges of non ionic surfactant Span 60 and Cholesterol were weighted accurately and dissolved in $10 \mathrm{ml}$ of ether in a small beaker. In another beaker $10 \mathrm{ml}$ phosphate buffer $\mathrm{pH} 6.8$ and $51.14 \mathrm{mg}$ active pharmaceutical ingredient Valsartan were taken. Then the dissolved surfactant/lipid solution was taken into a syringe and injected slowly at a rate of 0.25 $\mathrm{ml} / \mathrm{min}$, via a 24 gauge needle in phosphate buffer $\mathrm{pH}$ 6.8 containing Valsartan which was magnetically stirred at $500 \mathrm{rpm}$ continuously and maintained at $60^{\circ} \mathrm{C}-65^{\circ} \mathrm{C}$ for $30 \mathrm{~min}$. As the lipid solution was injected slowly into the aqueous phase, vaporization of ether leads to the formation of niosomes.

Table 3: Formulations of Valsartan loaded Niosomes

\begin{tabular}{ccccc}
\hline $\begin{array}{c}\text { S. } \\
\text { No. }\end{array}$ & $\begin{array}{c}\text { Formulation } \\
\text { code }\end{array}$ & $\begin{array}{c}\text { Valsartan } \\
\mathbf{( \% )}\end{array}$ & $\begin{array}{c}\text { Span } \mathbf{6 0} \\
\mathbf{( \% )}\end{array}$ & $\begin{array}{c}\text { Cholesterol } \\
\mathbf{( \% )}\end{array}$ \\
\hline 1. & V1 & 1.0 & 0.5 & 1.0 \\
2. & V2 & 1.0 & 1.0 & 1.0 \\
3. & V3 & 1.0 & 1.5 & 1.0 \\
4. & V4 & 1.0 & 2.0 & 1.0 \\
5. & V5 & 1.0 & 2.5 & 1.0 \\
6. & V6 & 1.0 & 3.0 & 1.0 \\
7. & V7 & 1.0 & 3.5 & 1.0 \\
8. & V8 & 1.0 & 4.0 & 1.0 \\
9. & V9 & 1.0 & 4.5 & 1.0 \\
\hline
\end{tabular}

Note: All formulation contains $10 \mathrm{ml}$ diethyl ether.

\section{Evaluation parameters for Medicated Niosomes Organoleptic properties}

The medicated niosomes were evaluated for colour, odour and appearance.

$\mathrm{pH}$

The $\mathrm{pH}$ of medicated niosomes was checked by digital $\mathrm{pH}$ meter.

\section{Total drug content}

Assay of medicated niosomes were carried out by U.V. method. Two $\mathrm{ml}$ of niosome was dissolved into $50 \mathrm{ml}$ Phosphate buffer solution having $\mathrm{pH}$ 6.8. The sample was stirred at $100 \mathrm{rpm}$ to break the niosomes. Drug content was determined using UV spectrophotometer at respective absorption maxima.

Mean particle size and Polydispersibility index

The particle size analysis of the formulation (V7) was determined using Beckman particle size determination technique. The graph of particle size distribution was shown in Fig. 10.

\section{Entrapment efficiency}

Unentrapped drug from niosome was separated by centrifugation method. Niosomes were centrifuged at $20,000 \mathrm{rpm}$ at controlled temperature of $4^{\circ} \mathrm{C}$ for $60 \mathrm{~min}$. By using UV spectroscopy unentrapped drug was quantified at respective absorption maxima. The results of medicated niosomes were shown in Table 17.

\section{Zeta potential}

Zeta potential of the dispersion was determined by Malvern zetameter. Time duration for zeta potential determination was $60 \mathrm{~s}$ and charge was find out. Typical graphs for zeta potential of medicated niosomes were shown in Fig. 11.

In-vitro Drug Release Studies

The release of valsartan from niosomes was determined by using membrane diffusion technique. The niosomal formulation equivalent to $51.14 \mathrm{mg}$ of valsartan was placed in a glass tube of diameter $2.5 \mathrm{~cm}$ with an 
effective length of $8 \mathrm{~cm}$ which was tied with previously soaked cellulose membrane (12,000-14,000 Da Molecular weight cut off), which acts as a donor compartment. The glass tube was placed in a beaker containing $100 \mathrm{ml}$ of phosphate buffer ( $\mathrm{pH}$ 6.8), acting as a receptor compartment. The whole assembly was fixed in such a way that the lower end of tube containing suspension was just touching (1-2 $\mathrm{mm}$ depth) the surface of diffusion medium. The temperature of receptor medium was maintained at 37 $\pm 5^{\circ} \mathrm{C}$ and was agitated at the speed of $100 \mathrm{rpm}$ using magnetic stirrer. Aliquots of $5 \mathrm{ml}$ sample were withdrawn periodically and after each withdrawal same volume of medium was replaced. The collected samples were analyzed at $250 \mathrm{~nm}$ in double beam UVVIS spectrophotometer using Phosphate Buffer (pH 6.8) as blank. [23]

Optimization Procedure: Among the nine formulations prepared, optimization of the best formulation was done based on the In-vitro drug release, total drug content and \% entrapment efficiency results.

\begin{tabular}{|c|c|c|}
\hline $\begin{array}{l}\text { S. } \\
\text { No }\end{array}$ & Test Parameters & Results \\
\hline 1. & Physical Appearance & A white powder \\
\hline 2. & $\begin{array}{c}\lambda \max \text { by UV spectroscopy (In } \\
\text { Methanol) }\end{array}$ & $250 \mathrm{~nm}$ \\
\hline 3. & Melting point & $102^{\circ} \mathrm{C}-107^{\circ} \mathrm{C}$ \\
\hline 4. & Loss on Drying & $0.41 \%$ (NMT $0.5 \%)$ \\
\hline \multirow{5}{*}{5.} & Methanol & 0.653 \\
\hline & Water & 0.160 \\
\hline & $0.1 \mathrm{~N} \mathrm{HCl}, \mathrm{pH} 1.2$ & 0.081 \\
\hline & $\begin{array}{l}\text { Phosphate buffer, } \mathrm{pH} \\
6.8\end{array}$ & 1.321 \\
\hline & $\begin{array}{c}\text { Phosphate buffer, } \mathrm{pH} \\
7.4\end{array}$ & 1.384 \\
\hline 6. & $\%$ Purity & $\begin{array}{c}99.86 \%(98.0 \%- \\
102.0 \%)\end{array}$ \\
\hline \multirow{6}{*}{7.} & \multicolumn{2}{|c|}{ Powder characterization } \\
\hline & Angle of Repose $\left(^{\circ}\right)$ & 16.46 \\
\hline & Bulk density (g/ml) & 0.4137 \\
\hline & Tapped density (g/ml) & 0.5578 \\
\hline & Carr's index & 42.361 \\
\hline & Hausner's ratio & 1.7328 \\
\hline
\end{tabular}

\section{RESULTS AND DISCUSSION}

\section{Preformulation study}

\section{Characterization of Pure drugs}

From the above results it was concluded that all the practical results were complied with theoretical values. The melting point of Valsartan was found to be $102^{\circ} \mathrm{C}$ $107^{\circ} \mathrm{C}$ which complies with theoretical values thus indicating purity of obtained drug sample. Valsartan has poor solubility in $0.1 \mathrm{~N} \mathrm{HCl}$ but its permeability was found to be more towards acidic side. Hence further emphasis was given to evaluate the drug dissolution at this particular media along with $\mathrm{pH} 6.8$ buffer as its solubility was found to be comparatively more at this particular media. From the solubility study data Valsartan also shows lower solubility in water. Powder characteristics indicate that Valsartan has good flowability.

\section{FTIR spectroscopy}

The FTIR spectrum (Fig. 1) of Valsartan individually revealed characteristic peaks which are shown in Table 5.

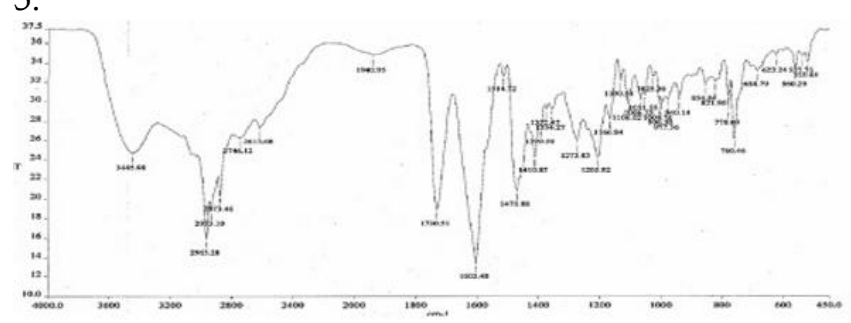

Fig. 1: FTIR Spectrum of Valsartan pure drug

Table 5: FTIR characteristic peaks of Valsartan pure drug

\begin{tabular}{|c|c|c|}
\hline $\begin{array}{c}\text { Reference peaks } \\
\left(\mathrm{cm}^{-1}\right)\end{array}$ & $\begin{array}{c}\text { Observed peaks } \\
\left(\mathrm{cm}^{-1}\right)\end{array}$ & Inference \\
\hline 1593.00 & 1598.99 & $\begin{array}{c}\mathrm{N}=\mathrm{N} \text { bending } \\
\text { (Aromatic secondary amine) }\end{array}$ \\
\hline 1410.00 & 1409.96 & $\mathrm{C}=\mathrm{C}$ stretching \\
\hline 2870.00 & 2872.01 & C-H stretching (Alkane) \\
\hline 1730.00 & 1726.29 & $\begin{array}{c}\mathrm{C}=\mathrm{O} \text { stretching }(\text { Acyclic } \\
\text { saturated })\end{array}$ \\
\hline
\end{tabular}

FTIR spectra of the Valsartan were recorded in the range of $400-4000 \mathrm{~cm}^{-1}$. The principal IR peaks were all observed at $1598.99 \mathrm{~cm}^{-1}, 1409.96 \mathrm{~cm}^{-1}, 2872.1 \mathrm{~cm}^{-1}$ and $1726.29 \mathrm{~cm}^{-1}$ in the above spectra of Valsartan. These observed principal peaks were comparable to the reference peaks of the Valsartan. This observation confirmed the purity and authenticity of the Valsartan.

Differential scanning Calorimetry (DSC) study

In order to confirm physical state of Valsartan in finished dosage form, DSC of Valsartan was carried out and showed in Fig. 2.

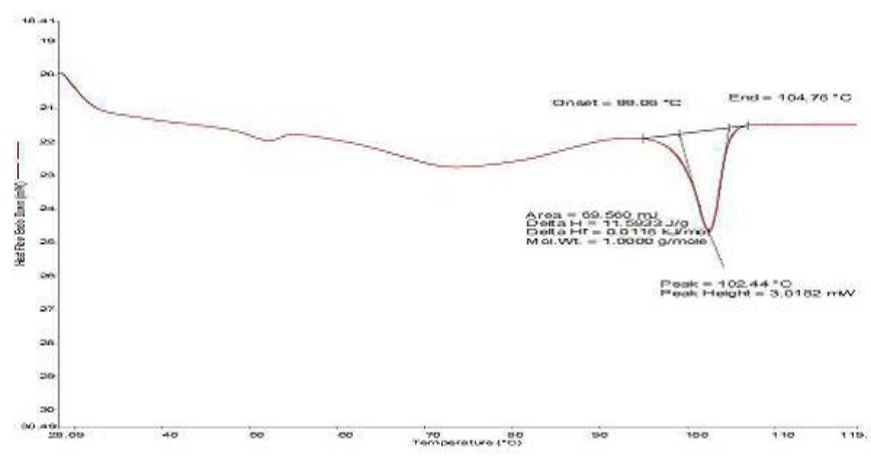

Fig. 2: DSC graph of Valsartan pure drug

DSC thermogram of Valsartan was recorded in the range of $20-119^{\circ} \mathrm{C}$. The DSC thermogram of Valsartan showed sharp endothermic peak at its melting point of $104.76^{\circ} \mathrm{C}$. This observation confirmed the purity and authenticity of the Valsartan.

Drug excipients compatibility studies

Physical change

The samples were checked for physical changes such as liquefaction, discoloration, odour and no changes observed during compatibility study.

Fourier Transform Infrared Spectroscopy (FTIR)

There was no shift in the characteristic peak of drug in the spectra of drug: drug and drug: excipients. FTIR 
Spectrophotometric analysis shows no evidence of interaction between drug and studied excipients.

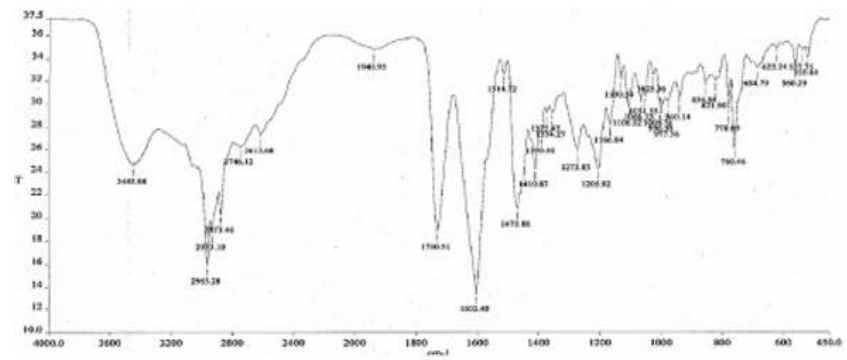

Fig. 3: FTIR Spectrum of Valsartan pure drug

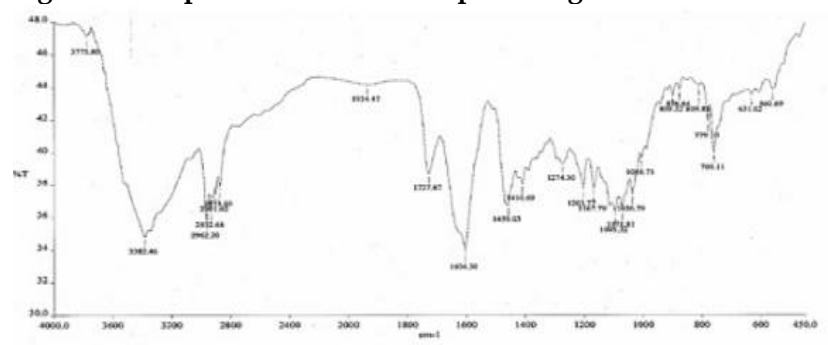

Fig. 4: FTIR Spectrum of Valsartan + Cholesterol

Analytical method development and validation Preparation of standard curve of Valsartan

The drug is freely soluble in methanol hence it is chosen as a solvent for developing the method. Valsartan exhibits maximum absorbance at $250 \mathrm{~nm}$ and obeyed Beer's law in the range of $5-40 \mu \mathrm{g} / \mathrm{ml}$. The results of calibration curve preparation were showed in Table 6 and Fig. 5.

Table 6: Standard calibration curve data of Valsartan in Methanol at $\lambda \max 250 \mathrm{~nm}$

\begin{tabular}{cccccc}
\hline $\begin{array}{c}\text { S. } \\
\text { No. }\end{array}$ & $\begin{array}{c}\text { Concentration } \\
\text { (ug/ml) }\end{array}$ & \multicolumn{3}{c}{ Absorbance } & $\begin{array}{c}\text { Absorbance } \\
\text { (Mean* } \pm \text { SD) }\end{array}$ \\
\hline 1 & 5 & 0.103 & 0.102 & 0.104 & $0.103 \pm 0.001$ \\
2 & 10 & 0.215 & 0.219 & 0.219 & $0.217 \pm 0.0023$ \\
3 & 15 & 0.319 & 0.318 & 0.321 & $0.319 \pm 0.0015$ \\
4 & 20 & 0.454 & 0.456 & 0.453 & $0.454 \pm 0.0015$ \\
5 & 25 & 0.592 & 0.59 & 0.592 & $0.592 \pm 0.0012$ \\
6 & 30 & 0.763 & 0.762 & 0.76 & $0.761 \pm 0.0015$ \\
7 & 35 & 0.92 & 0.92 & 0.921 & $0.920 \pm 0.0005$ \\
8 & 40 & 1.234 & 1.233 & 1.235 & $1.234 \pm 0.001$ \\
\hline
\end{tabular}

SD: Standard deviation, *: Mean of each 3 reading

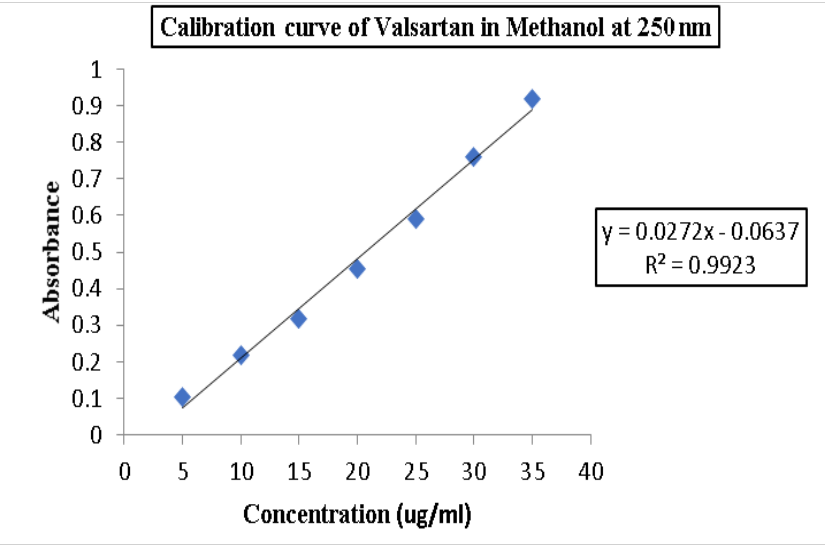

Fig. 5: Standard calibration curve of Valsartan in Methanol

Validation of analytical method of Valsartan Linearity and range
Valsartan exhibits maximum absorbance at $250 \mathrm{~nm}$ and obeyed Beer's law in the range of $5-40 \mu \mathrm{g} / \mathrm{ml}$. The results of calibration curve preparation were showed in Table 6 and Fig. 5.

Accuracy (\% recovery)

The $\%$ recoveries obtained were $98.47 \%-108.07 \%$. The results of recovery study were showed in Table 7 .

Table 7: Data of recovery study for Valsartan in Methanol at $\lambda \max$ $250 \mathrm{~nm}$

\begin{tabular}{cccccc}
\hline $\begin{array}{c}\text { S. } \\
\text { No }\end{array} \begin{array}{c}\text { Amount } \\
\text { of drug } \\
\text { taken } \\
(\boldsymbol{\mu g} / \mathbf{m l})\end{array}$ & $\begin{array}{c}\text { Amount } \\
\text { of drug } \\
\text { added } \\
(\boldsymbol{\mu g} / \mathbf{m l})\end{array}$ & $\begin{array}{c}\text { Total } \\
\text { amount } \\
\text { of drug } \\
(\boldsymbol{\mu} \mathbf{g} / \mathbf{m l})\end{array}$ & $\begin{array}{c}\text { Amount } \\
\text { of drug } \\
\text { found } \\
(\boldsymbol{\mu g} / \mathbf{m l})\end{array}$ & $\begin{array}{c}\% \\
\text { Recovery }\end{array}$ \\
\hline 1 & 10 & - & 10 & - & - \\
2 & 10 & 5 & 15 & 14.77 & 98.47 \\
3 & 10 & 10 & 20 & 20.68 & 103.44 \\
4 & 10 & 15 & 25 & 27.01 & 108.07 \\
\hline
\end{tabular}

\section{Precision}

The $\%$ RSD found $0.123 \%-1.473 \%$ for intraday and $0.046 \%-1.459 \%$ for interday.

Precision revealed that the proposed method is precise. Results were showed in Table 8 and Table 9.

Table 8: Intraday precision data for Valsartan in Methanol at $250 \mathrm{~nm}$

\begin{tabular}{|c|c|c|c|c|c|c|}
\hline \multirow{2}{*}{$\begin{array}{l}\text { S. } \\
\text { No }\end{array}$} & \multirow{2}{*}{$\begin{array}{c}\text { Concentration } \\
(\mu \mathrm{g} / \mathrm{ml})\end{array}$} & \multicolumn{3}{|c|}{ Absorbance } & \multirow{2}{*}{$\begin{array}{c}\text { Absorbance } \\
(\text { Mean* } \pm \text { SD) }\end{array}$} & \multirow{2}{*}{$\begin{array}{c}\% \\
\text { RSD } \\
\end{array}$} \\
\hline & & 1 & 2 & 3 & & \\
\hline 1 & 5 & 0.102 & 0.104 & 0.105 & $0.104 \pm 0.0015$ & 1.473 \\
\hline 2 & 10 & 0.22 & 0.218 & 0.217 & $0.218 \pm 0.0015$ & 0.699 \\
\hline 3 & 15 & 0.321 & 0.324 & 0.325 & $0.323 \pm 0.0020$ & 0.643 \\
\hline 4 & 20 & 0.456 & 0.454 & 0.453 & $0.454 \pm 0.0015$ & 0.336 \\
\hline 5 & 25 & 0.591 & 0.589 & 0.588 & 0.0015 & 0.259 \\
\hline 6 & 30 & 0.759 & 0.763 & 0.762 & $0.761 \pm 0.0021$ & 0.273 \\
\hline 7 & 35 & 0.919 & 0.921 & 0.923 & $0.921 \pm 0.002$ & 0.217 \\
\hline 8 & 40 & 1.236 & 1.233 & 1.235 & $1.234 \pm 0.0015$ & 0.123 \\
\hline
\end{tabular}

SD: Standard deviation, RSD: Relative standard deviation, ${ }^{*}$ : Mean of each 3 reading

Table 9: Interday precision data for Valsartan in Methanol

\begin{tabular}{ccccccc}
\hline $\begin{array}{c}\text { S. } \\
\text { No }\end{array}$ & $\begin{array}{c}\text { Concentration } \\
(\boldsymbol{\mu} / \mathbf{m} / \mathbf{m})\end{array}$ & \multicolumn{3}{c}{ Absorbance } & $\begin{array}{c}\text { Absorbance } \\
\text { (Mean* } \mathbf{S D})\end{array}$ & $\begin{array}{c}\% \\
\text { RSD }\end{array}$ \\
\hline 1 & 5 & 0.103 & 0.106 & 0.105 & $0.105 \pm 0.0015$ & 1.459 \\
2 & 10 & 0.216 & 0.215 & 0.213 & $0.215 \pm 0.0015$ & 0.711 \\
3 & 15 & 0.318 & 0.32 & 0.319 & $0.319 \pm 0.001$ & 0.313 \\
4 & 20 & 0.452 & 0.45 & 0.453 & $0.452 \pm 0.0015$ & 0.338 \\
5 & 25 & 0.589 & 0.588 & 0.591 & $0.589 \pm 0.0015$ & 0.259 \\
6 & 30 & 0.761 & 0.759 & 0.76 & $0.760 \pm 0.001$ & 0.131 \\
7 & 35 & 0.923 & 0.921 & 0.924 & $0.923 \pm 0.0015$ & 0.165 \\
8 & 40 & 1.231 & 1.23 & 1.231 & $1.231 \pm 0.0005$ & 0.046 \\
\hline
\end{tabular}

SD: Standard deviation, RSD: Relative standard deviation, ${ }^{*}$ : Mean of each 3 reading

\section{Limit of detection (LOD)}

Limit of detection (LOD) of Valsartan was found $7.522 \mu \mathrm{g} / \mathrm{ml}$.

\section{Limit of quantitation (LOQ)}

Limit of quantitation (LOQ) of Valsartan was found $22.795 \mu \mathrm{g} / \mathrm{ml}$.

\section{Summary of Validation Parameters}

The results of the analysis of Valsartan by the proposed method were highly reproducible, and reliable which conclude that the proposed method is highly simple, sensitive, reproducible, economic, less time consuming and easy to apply for routine analysis of Valsartan in Methanol. 
Table 10: Summary of validation parameters of Valsartan in Methanol

\begin{tabular}{|c|c|c|}
\hline S. No & Validation parameters & Results \\
\hline 1 & Linearity range $(\mu \mathrm{g} / \mathrm{ml})$ & $5-40$ \\
\hline 2 & Linearity equation & $y=0.0272 x-0.0637$ \\
\hline 3 & $\begin{array}{c}\text { Linearity (R2, Correlation } \\
\text { coefficient) }\end{array}$ & 0.9923 \\
\hline \multirow{2}{*}{4} & Precision (\% $\quad$ Intraday & $0.123 \%-1.473 \%$ \\
\hline & RSD) Interday & $0.046 \%-1.459 \%$ \\
\hline 5 & Accuracy (\% Recovery) & $98.47 \%-108.07 \%$ \\
\hline 6 & LOD $(\mu \mathrm{g} / \mathrm{ml})$ & 7.522 \\
\hline 7 & $\mathrm{LOQ}(\mu \mathrm{g} / \mathrm{ml})$ & 22.795 \\
\hline
\end{tabular}

RSD: Relative standard deviation, LOD: Limit of detection, LOQ: Limit of quantitation

Table 11: Observation of placebo niosomes

\begin{tabular}{|c|c|c|c|c|}
\hline $\begin{array}{l}\text { S. } \\
\text { No. }\end{array}$ & $\begin{array}{l}\text { Batch } \\
\text { No. }\end{array}$ & $\begin{array}{c}\text { Span } 60 \\
(\%)\end{array}$ & $\begin{array}{c}\text { Cholesterol } \\
(\%)\end{array}$ & Result \\
\hline 1. & $\mathrm{~T} 1$ & 0.1 & 0.5 & $\begin{array}{c}\text { Dispersion was not } \\
\text { obtained }\end{array}$ \\
\hline 2. & $\mathrm{~T} 2$ & 0.2 & 0.5 & $\begin{array}{c}\text { Dispersion was not } \\
\text { obtained }\end{array}$ \\
\hline 3. & T3 & 0.3 & 0.5 & $\begin{array}{l}\text { Dispersion was not } \\
\text { obtained }\end{array}$ \\
\hline 4. & $\mathrm{~T} 4$ & 0.4 & 0.5 & $\begin{array}{c}\text { Dispersion was not } \\
\text { obtained }\end{array}$ \\
\hline 5. & T5 & 0.5 & 0.5 & $\begin{array}{l}\text { Milky white dispersion } \\
\text { was obtained }\end{array}$ \\
\hline 6. & T6 & 0.6 & 0.5 & Separation was obtained \\
\hline 7. & $\mathrm{~T} 7$ & 0.7 & 0.5 & Separation was obtained \\
\hline 8. & T8 & 0.8 & 0.5 & Separation was obtained \\
\hline 9. & T9 & 0.9 & 0.5 & Separation was obtained \\
\hline 10. & $\mathrm{~T} 10$ & 1.0 & 0.5 & Separation was obtained \\
\hline 11. & T11 & 0.1 & 1 & $\begin{array}{c}\text { Dispersion was not } \\
\text { obtained }\end{array}$ \\
\hline 12. & T12 & 0.2 & 1 & $\begin{array}{c}\text { Dispersion was not } \\
\text { obtained }\end{array}$ \\
\hline 13. & T13 & 0.3 & 1 & $\begin{array}{c}\text { Dispersion was not } \\
\text { obtained }\end{array}$ \\
\hline 14. & T14 & 0.4 & 1 & $\begin{array}{c}\text { Dispersion was not } \\
\text { obtained }\end{array}$ \\
\hline 15. & T15 & 0.5 & 1 & $\begin{array}{l}\text { Milky white dispersion } \\
\text { was obtained }\end{array}$ \\
\hline 16. & T16 & 1.0 & 1 & $\begin{array}{l}\text { Milky white dispersion } \\
\text { was obtained }\end{array}$ \\
\hline 17. & T17 & 2.0 & 1 & $\begin{array}{l}\text { Milky white dispersion } \\
\text { was obtained }\end{array}$ \\
\hline 18. & T18 & 3.0 & 1 & $\begin{array}{l}\text { Milky white dispersion } \\
\text { was obtained }\end{array}$ \\
\hline 19. & T19 & 4.0 & 1 & $\begin{array}{l}\text { Milky white dispersion } \\
\text { was obtained }\end{array}$ \\
\hline 20. & $\mathrm{~T} 20$ & 5.0 & 1 & Separation was obtained \\
\hline 21. & $\mathrm{~T} 21$ & 6.0 & 1 & Separation was obtained \\
\hline 22. & $\mathrm{~T} 22$ & 7.0 & 1 & Separation was obtained \\
\hline 23. & $\mathrm{~T} 23$ & 0.1 & 1.5 & $\begin{array}{c}\text { Dispersion was not } \\
\text { obtained }\end{array}$ \\
\hline 24. & $\mathrm{~T} 24$ & 0.2 & 1.5 & $\begin{array}{c}\text { Dispersion was not } \\
\text { obtained }\end{array}$ \\
\hline 25. & $\mathrm{~T} 25$ & 0.3 & 1.5 & $\begin{array}{c}\text { Dispersion was not } \\
\text { obtained }\end{array}$ \\
\hline 26. & $\mathrm{~T} 26$ & 0.4 & 1.5 & $\begin{array}{c}\text { Dispersion was not } \\
\text { obtained. }\end{array}$ \\
\hline 27. & $\mathrm{~T} 27$ & 0.5 & 1.5 & $\begin{array}{l}\text { Milky white dispersion } \\
\text { was obtained }\end{array}$ \\
\hline 28. & T28 & 1.0 & 1.5 & $\begin{array}{l}\text { Milky white dispersion } \\
\text { was obtained }\end{array}$ \\
\hline 29. & T29 & 2.0 & 1.5 & Separation was obtained \\
\hline 30. & T30 & 3.0 & 1.5 & Separation was obtained \\
\hline
\end{tabular}

Formulation development Placebo Niosomes
Non-ionic surfactant concentration from $0.1-0.4 \% \mathrm{w} / \mathrm{v}$ did not give proper dispersion this may be due to insufficient concentration of non-ionic surfactant to form uniform spherical vesicle. Whereas surfactant concentration more than $0.6 \% \mathrm{w} / \mathrm{v}$ with $0.5 \% \mathrm{w} / \mathrm{v}$ cholesterol, $5.0 \% \mathrm{w} / \mathrm{v}$ with $1.0 \% \mathrm{w} / \mathrm{v}$ cholesterol and $2.0 \% \mathrm{w} / \mathrm{v}$ with $1.5 \% \mathrm{w} / \mathrm{v}$ cholesterol showed cracking this may be due to precipitation of surfactant.

Batch no. T5, T15-T19, T27-T28 gave milky white dispersion in which the concentration of surfactant was in the range of $0.5-4.5 \% \mathrm{w} / \mathrm{v}$ and hence, this were taken for the further optimization with $1 \%$ Cholesterol concentration.

\begin{tabular}{|c|c|c|c|c|c|c|}
\hline $\begin{array}{l}\text { Batch } \\
\text { No }\end{array}$ & $\begin{array}{c}\text { Appearance/ } \\
\text { Colour }\end{array}$ & Odour & Texture & $\begin{array}{c}\text { Creaming } \\
\text { volume }\end{array}$ & $\mathrm{pH}$ & $\begin{array}{c}\text { Changes } \\
\text { after } 15 \\
\mathrm{~d} \\
\end{array}$ \\
\hline $\mathrm{T}-5$ & Milky white & Odourless & Smooth & $\begin{array}{c}\text { No } \\
\text { change }\end{array}$ & $\begin{array}{l}4.5- \\
5.6\end{array}$ & $\begin{array}{c}\text { No } \\
\text { changes }\end{array}$ \\
\hline $\begin{array}{l}\text { T15- } \\
\text { T19 }\end{array}$ & Milky white & Odourless & Smooth & $\begin{array}{c}\text { No } \\
\text { change }\end{array}$ & $\begin{array}{l}4.5- \\
5.6\end{array}$ & $\begin{array}{c}\text { No } \\
\text { changes }\end{array}$ \\
\hline $\begin{array}{l}\text { T27- } \\
\text { T28 }\end{array}$ & Milky white & Odourless & Smooth & $\begin{array}{c}\text { No } \\
\text { change }\end{array}$ & $\begin{array}{l}4.5- \\
5.6\end{array}$ & $\begin{array}{c}\text { No } \\
\text { changes }\end{array}$ \\
\hline
\end{tabular}

Table 13: Effect of processing parameters on particle size distribution

\begin{tabular}{cc}
\hline Parameters & Effect on particle size distribution \\
Rapid addition & $\begin{array}{c}\text { Rate of addition } \\
\text { Non uniform size distribution } \\
\text { Uniform size distribution }\end{array}$ \\
$\begin{array}{c}\text { Drop wise addition during min } \\
\text { Stirring speed } \\
250 \mathrm{RPM}\end{array}$ & $\begin{array}{c}\text { Non uniform size distribution } \\
\text { Non uniform size distribution }\end{array}$ \\
$500 \mathrm{RPM}$ & Uniform size distribution \\
$500 \mathrm{RPM}$ & Stirring time \\
$5 \mathrm{~min}$ & Non uniform size distribution \\
$10 \mathrm{~min}$ & Non uniform size distribution \\
$20 \mathrm{~min}$ & Non uniform size distribution \\
$30 \mathrm{~min}$ & Uniform size distribution \\
& Stirring temperature \\
$50^{\circ} \mathrm{C}-55^{\circ} \mathrm{C}$ & Non uniform size distribution \\
$60^{\circ} \mathrm{C}-65^{\circ} \mathrm{C}$ & Uniform size distribution \\
$65^{\circ} \mathrm{C}-70^{\circ} \mathrm{C}$ & Non uniform size distribution \\
\hline
\end{tabular}

Table 14: Final selected chemical and processing parameters for formulation of Niosomes

\begin{tabular}{cc}
\hline \multicolumn{2}{c}{ Optimized parameters } \\
\hline Concentration of Span 60 & $0.5 \% \mathrm{w} / \mathrm{v}-4.5 \% \mathrm{w} / \mathrm{v}$ \\
Concentration of Cholesterol & $0.1 \% \mathrm{w} / \mathrm{v}$ \\
Rate of addition & Drop wise addition during min \\
Stirring speed & $500 \mathrm{RPM}$ \\
Stirring time & $30 \mathrm{~min}$ \\
Stirring temperature & $60^{\circ} \mathrm{C}-65^{\circ} \mathrm{C}$ \\
\hline
\end{tabular}
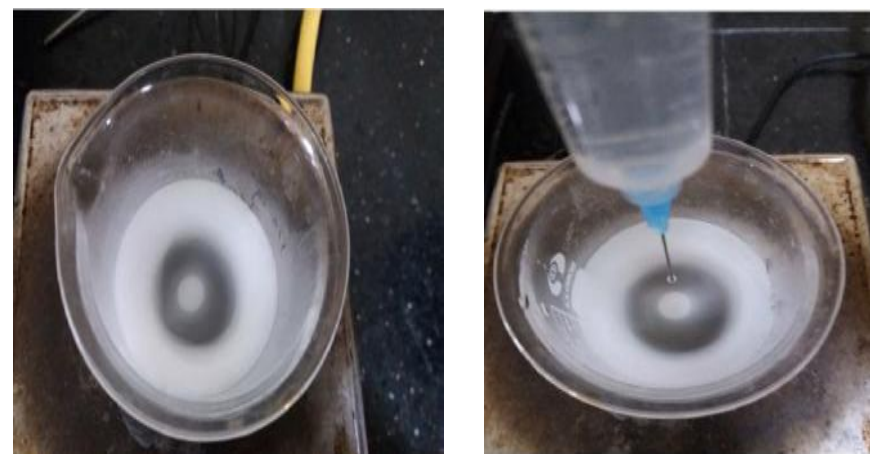

Fig. 6: Preparation of medicated niosome 


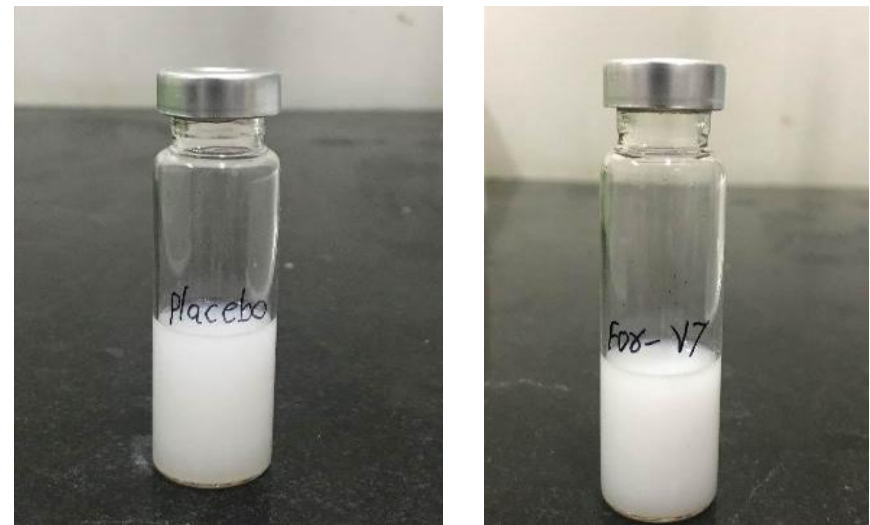

Fig. 7: Prepared placebo and Optimized V7 formulations

Therefore by carried out placebo niosome batches we have optimized chemical parameters and processing parameters. Chemical parameters i.e. concentration of span 60 \& cholesterol and processing parameters include rate of addition, stirring speed, stirring time and stirring temperature.

Evaluation parameters for Medicated Niosomes Organoleptic properties

The Valsartan niosomes were off-white in color, odourless, and fluid in nature. It was stable and did not show sedimentation. The results of Organoleptic properties i.e. Appearance, Colour and Odour for all the nine batches are summarize in below Table 15 .

Table 15: Organoleptic properties of medicated niosome

\begin{tabular}{ccc}
\hline Batch No & Appearance/Colour & Odour \\
\hline V1 & Milky white & Odourless \\
V2 & Milky white & Odourless \\
V3 & Milky white & Odourless \\
V4 & Milky white & Odourless \\
V5 & Milky white & Odourless \\
V6 & Milky white & Odourless \\
V7 & Milky white & Odourless \\
V8 & Milky white & Odourless \\
V9 & Milky white & Odourless \\
\hline
\end{tabular}

Table 16: $\mathrm{pH}$ and Total drug content of medicated niosome

\begin{tabular}{ccc}
\hline Batch No & pH & Drug content $(\% \pm \mathbf{S D})$ \\
\hline V1 & 4.7 & $89.23 \pm 1.75$ \\
V2 & 4.6 & $90.20 \pm 0.61$ \\
V3 & 5.1 & $89.13 \pm 0.79$ \\
V4 & 4.9 & $95.41 \pm 0.90$ \\
V5 & 4.7 & $97.76 \pm 1.50$ \\
V6 & 5.2 & $97.29 \pm 0.59$ \\
V7 & 5.4 & $\mathbf{9 9 . 5 2} \pm 0.97$ \\
V8 & 5.1 & $97.93 \pm 1.25$ \\
V9 & 4.8 & $98.45 \pm 1.19$ \\
\hline
\end{tabular}

SD: Standard deviation

\section{$\mathrm{pH}$ and Drug content}

$\mathrm{pH}$ was found to be in the range of 4.6-5.4. The drug content was found in the range of 89.13 to 99.52 . The results of $\mathrm{pH}$ value and Drug content for all the nine batches are summarize in below Table 16 .

Entrapment efficiency, Mean particle size and Polydispersibility index, Zeta potential

The Entrapment efficiency was found in range of 79.05 to 98.24. Formulation V7 shows highest \% entrapment efficiency values. The mean vesicle size of drug loaded niosomes of the different batches ranged between 2.52$3.42 \mu \mathrm{m}$. The polydispersvity index (PdI) was in the range of $0.325-0.420$ for drug loaded niosomes which indicates a narrow vesicle size distribution. The values of Zeta potential of the drug loaded niosomal formulation were in the range of -20.29 to $-30.55 \mathrm{mV}$. Values of zeta potential showed that the medicated niosomes had sufficient charge and mobility to inhibit aggregation of vesicles.

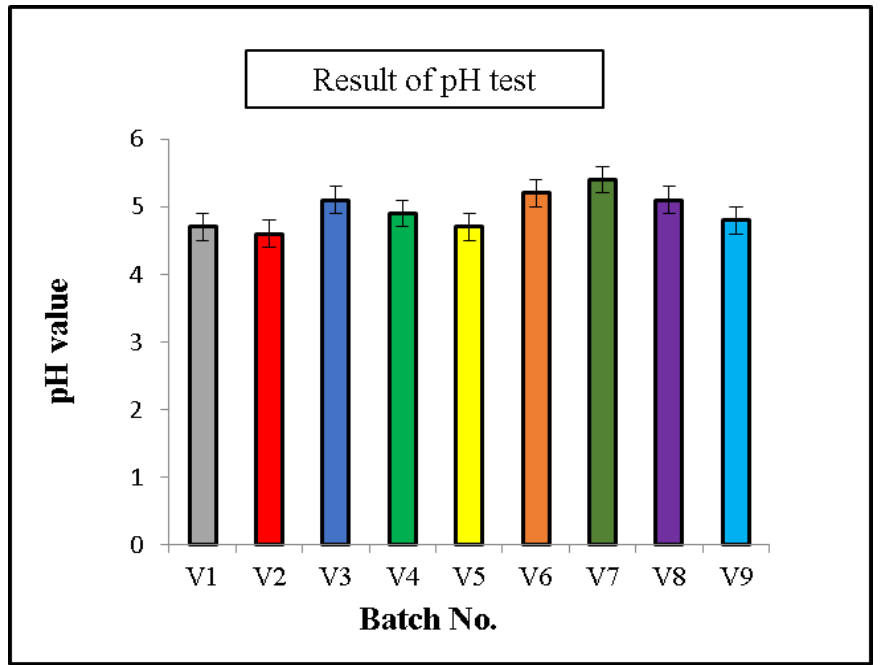

Fig. 8: Bar diagram of $\mathrm{pH}$ values of various niosome batches

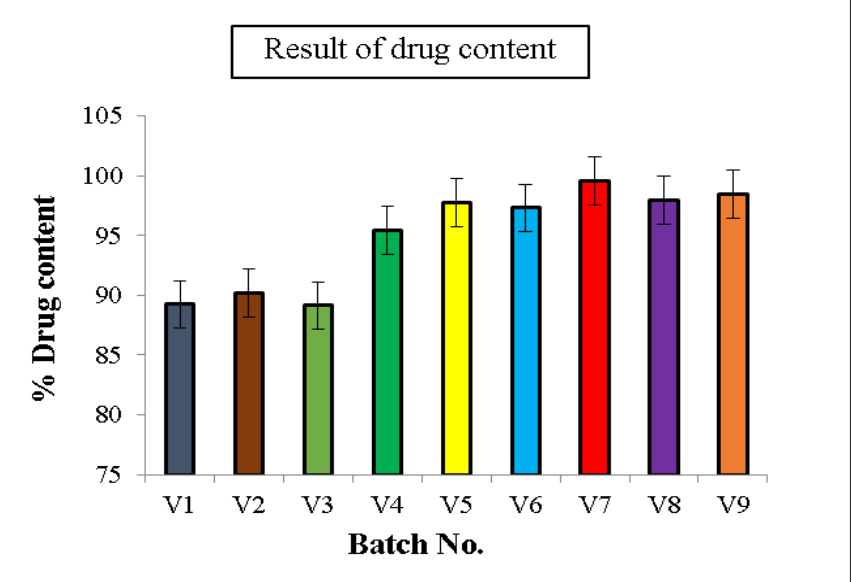

Fig. 9: Bar diagram of Total drug content of various niosome batches

The results of entrapment efficiency, mean particle size and polydispersibility index and zeta potential for all the nine batches are summarize in below Table 17.

\begin{tabular}{ccccc}
\multicolumn{6}{c}{ Table 17: Entrapment efficiency of medicated niosome } \\
\hline $\begin{array}{c}\text { Batch } \\
\text { No. }\end{array}$ & $\begin{array}{c}\text { Entrapment } \\
\text { Efficiency } \\
(\mathbf{\%}) \pm \text { SD }\end{array}$ & $\begin{array}{c}\text { Polydispersibility } \\
\text { index }\end{array}$ & $\begin{array}{c}\text { Particle } \\
\text { size }(\boldsymbol{\mu m}) \\
\pm \mathbf{S D}\end{array}$ & $\begin{array}{c}\text { Zeta } \\
\text { potential } \\
\mathbf{( M v ) \pm ~ S D ~}\end{array}$ \\
\hline V1 & $85.52 \pm 1.13$ & 0.411 & $2.76 \pm 0.84$ & $-27.77 \pm 1.55$ \\
V2 & $83.60 \pm 1.39$ & 0.389 & $2.99 \pm 0.97$ & $-24.84 \pm 0.79$ \\
V3 & $79.05 \pm 1.14$ & 0.420 & $3.24 \pm 0.86$ & $-20.29 \pm 1.03$ \\
V4 & $89.60 \pm 2.26$ & 0.385 & $3.08 \pm 0.55$ & $-25.44 \pm 0.92$ \\
V5 & $88.09 \pm 1.94$ & 0.325 & $3.20 \pm 0.90$ & $-21.07 \pm 1.75$ \\
V6 & $84.84 \pm 1.60$ & 0.370 & $3.42 \pm 0.77$ & $-24.57 \pm 0.16$ \\
V7 & $\mathbf{9 8 . 2 4} \pm \mathbf{1 . 5 0}$ & $\mathbf{0 . 3 8 7}$ & $\mathbf{2 . 5 2} \pm \mathbf{1 . 5 0}$ & $\mathbf{- 2 5 . 6 9 \pm 1 . 8 7}$ \\
V8 & $93.24 \pm 2.25$ & 0.404 & $2.90 \pm 0.60$ & $-28.27 \pm 0.28$ \\
V9 & $90.16 \pm 1.03$ & 0.395 & $3.32 \pm 0.61$ & $-30.55 \pm 0.28$ \\
\hline
\end{tabular}

SD: Standard deviation 


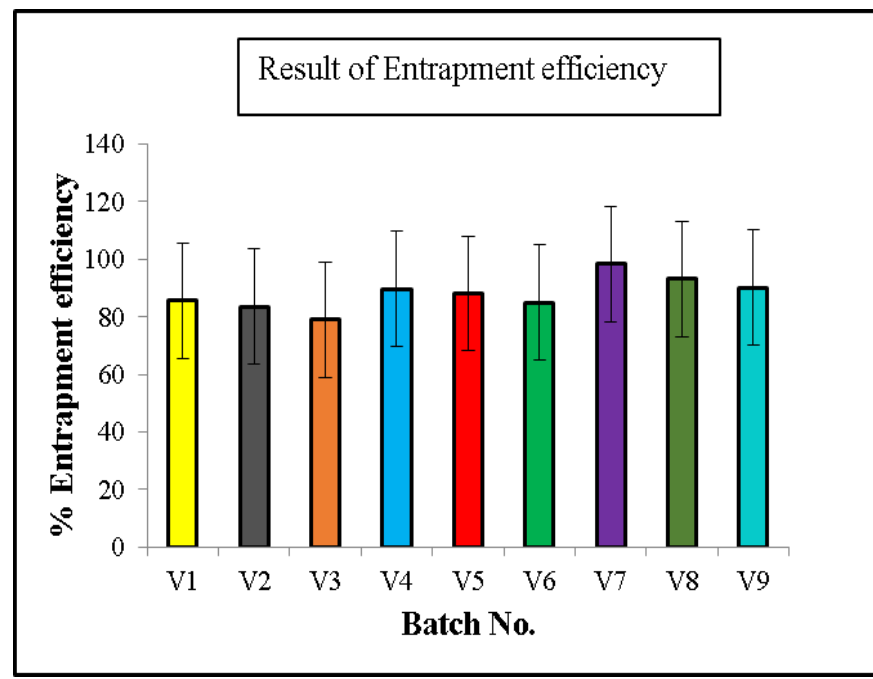

Fig. 10: Bar diagram of Entrapment efficiency values of various niosome batches

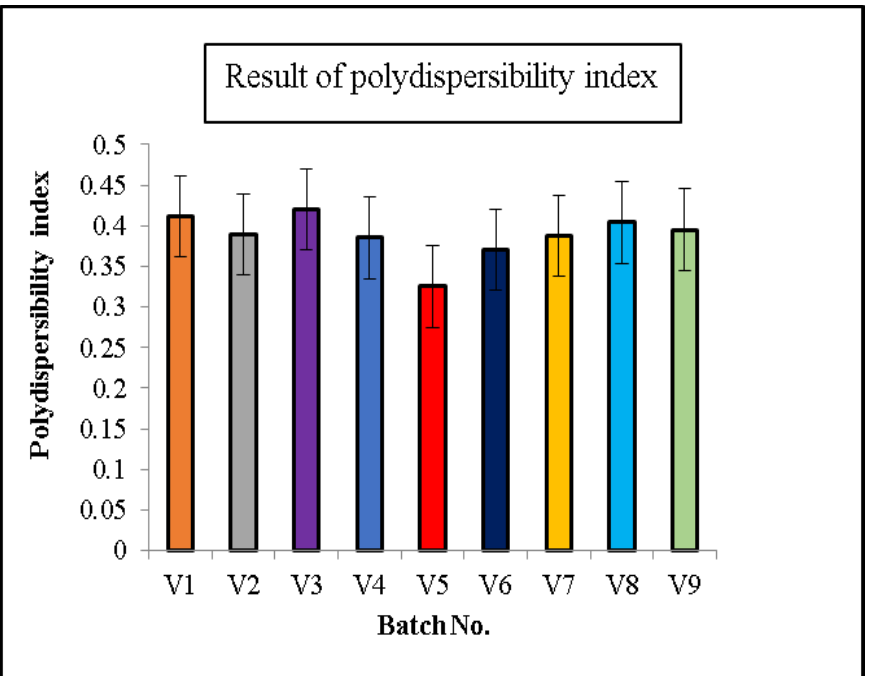

Fig. 11: Bar diagram of Polydispersibility index values of various niosome batches

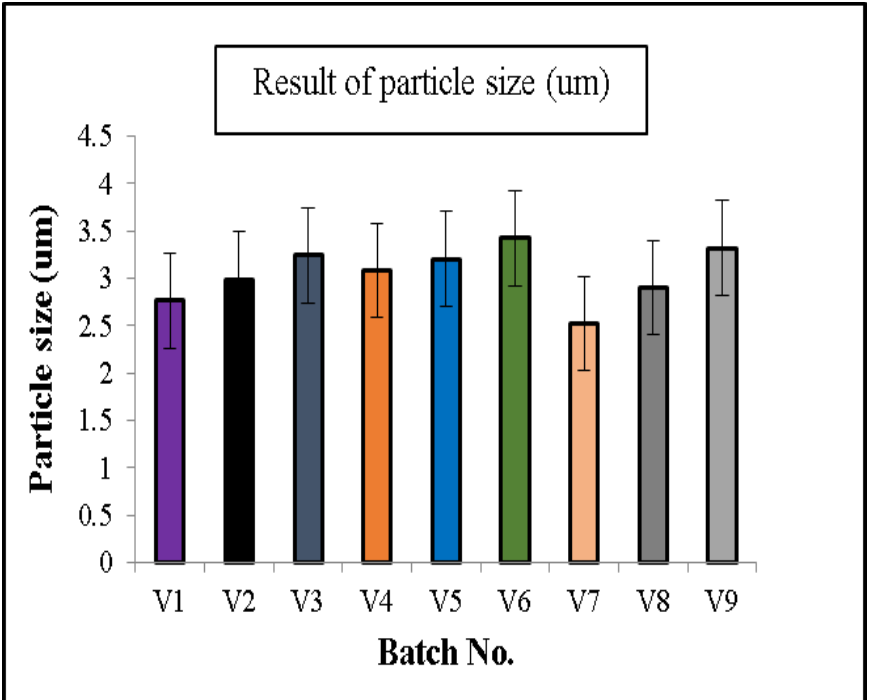

Fig. 12: Bar diagram of Particle size values of various niosome batches

\section{In-vitro drug release studies}

For all the nine formulations there was no initial burst release but the release was constant in a controlled manner for a period of time upto $24 \mathrm{~h}$. The best formulation is the one which provides good morphology (size and shape), high drug content, entrapment efficiency and controlled and prolonged drug release. Formulation V7 was considered to be the best formulation as the drug content, entrapment efficiency and the percent drug release were high for V7. This is the niosomal formulation containing comparatively high amount of surfactant prepared by ether injection method. The results of in-vitro drug release revealed that the drug was released in a controlled manner from all the formulations and V7 showed maximum drug release at the end of $24^{\text {th }} \mathrm{h}$. Hence from all the above results of morphology, drug content, entrapment efficiency and in-vitro drug release studies, it is proved that formulation V7 is the best and optimized formulation. Formulation code V7 has shown a promising formula for delivering the drug by which the bioavailability of the drug can be improved, side effects can be reduced, first pass hepatic metabolism of the drug can be avoided and finally the patient compliance can be improved.

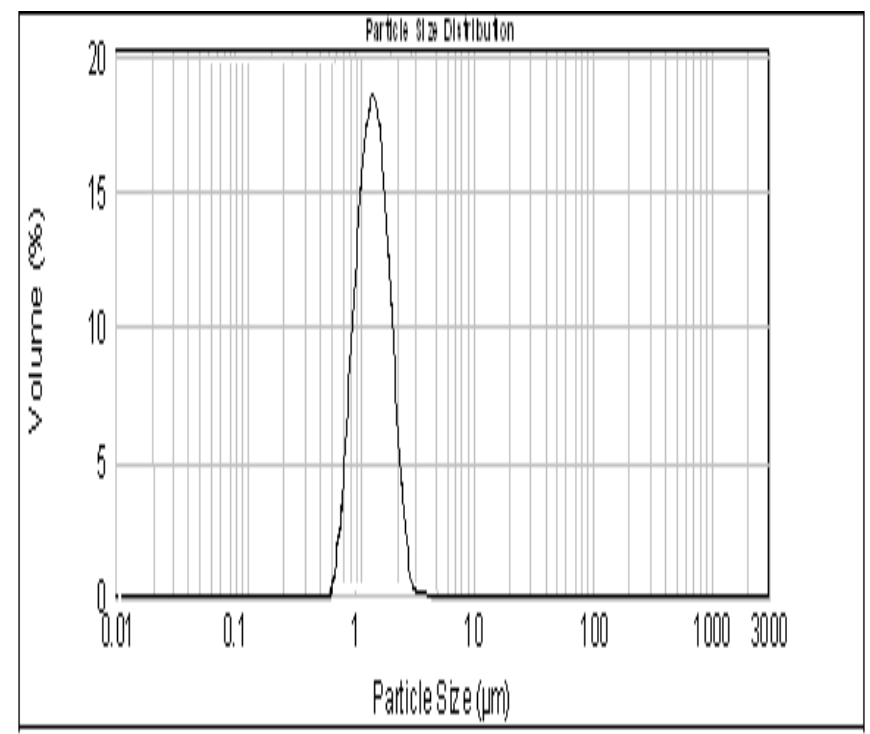

Fig. 13: Particle size distribution graph of optimized V7 formulation batch

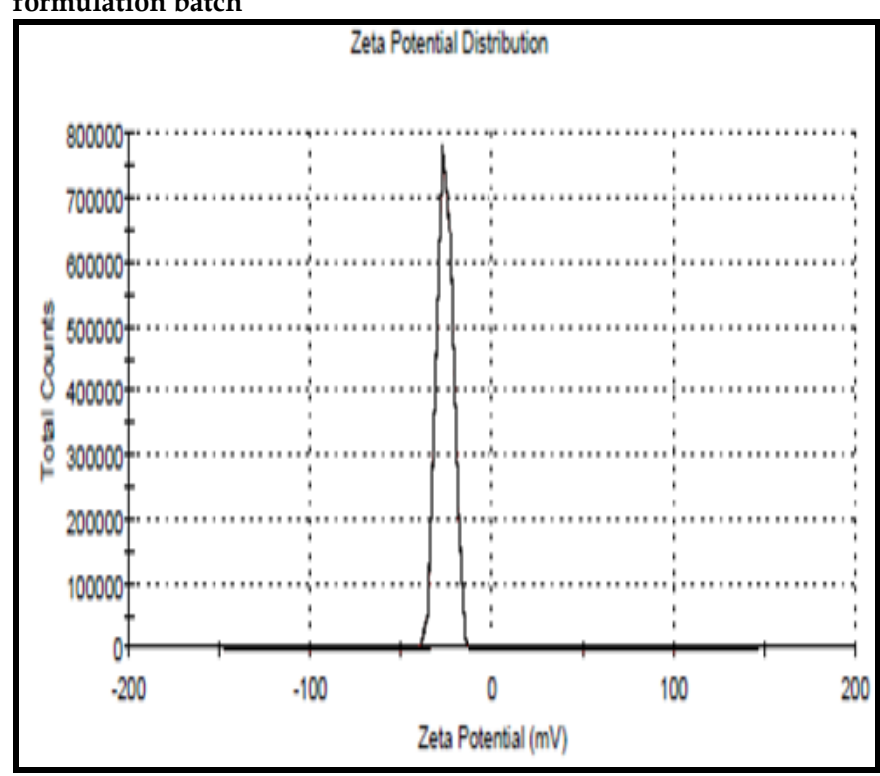

Fig. 14: A typical graph for zeta potential of V7 batch 


\begin{tabular}{|c|c|c|c|c|c|c|c|c|c|}
\hline \multirow{2}{*}{$\begin{array}{l}\text { Time } \\
\text { (h) }\end{array}$} & \multicolumn{9}{|c|}{$\%$ Cumulative drug release } \\
\hline & V1 & V2 & V3 & $\mathrm{V} 4$ & V5 & V6 & V7 & V8 & V9 \\
\hline 0 & 0 & 0 & 0 & 0 & 0 & 0 & 0 & 0 & 0 \\
\hline 2 & 4.45 & 5.02 & 4.22 & 5.25 & 4.45 & 5.24 & 6.45 & 3.45 & 3.56 \\
\hline 3 & 8.34 & 9.56 & 7.23 & 8.64 & 7.54 & 8.02 & 9.56 & 7.55 & 6.28 \\
\hline 4 & 10.11 & 12.11 & 10.25 & 11.43 & 10.96 & 12.89 & 15.23 & 9.95 & 9.25 \\
\hline 5 & 14.43 & 16.34 & 14.43 & 14.56 & 12.53 & 15.04 & 18.25 & 13.56 & 12.43 \\
\hline 6 & 24.21 & 24.5 & 22.58 & 23.41 & 19.96 & 20.48 & 26.95 & 21.11 & 19.55 \\
\hline 7 & 32.23 & 34.16 & 30.23 & 30.54 & 29.78 & 32.11 & 34.11 & 28.24 & 26.65 \\
\hline 8 & 39.55 & 40.11 & 36.55 & 37.78 & 38.57 & 40.67 & 42.56 & 42.05 & 33.43 \\
\hline 12 & 62.45 & 64.78 & 60.44 & 62.65 & 63.98 & 65.43 & 68.45 & 63.45 & 60.23 \\
\hline 18 & 82.61 & 83.49 & 82.54 & 86.56 & 85.46 & 88.9 & 92.36 & 78.59 & 75.43 \\
\hline 24 & 90.26 & 87.67 & 88.21 & 91.55 & 90.23 & 92.45 & 98.55 & 85.65 & 82.25 \\
\hline
\end{tabular}

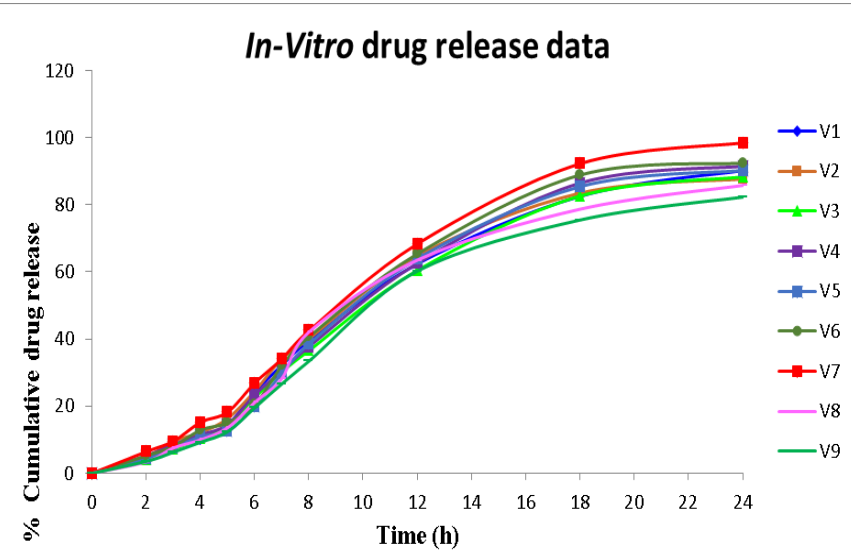

Fig. 15: In-vitro drug release data of medicated niosome formulations

$\%$ Drug released at $24 \mathrm{~h}$

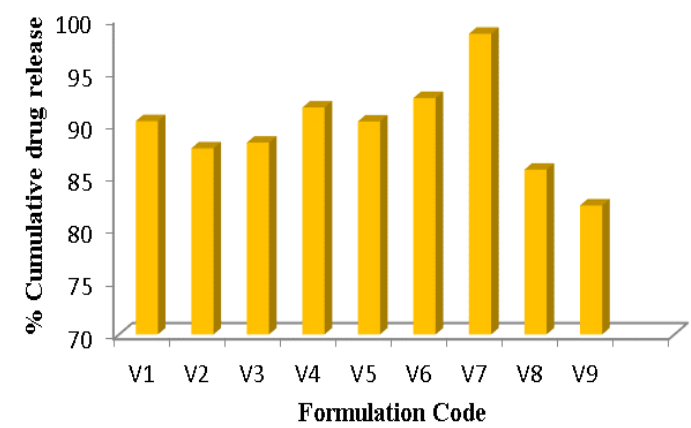

$\%$ Drug released at $24 \mathrm{~h}$

Fig. 16: Bar diagram of $\%$ drug release at $24 \mathrm{~h}$ for medicated niosome formulations

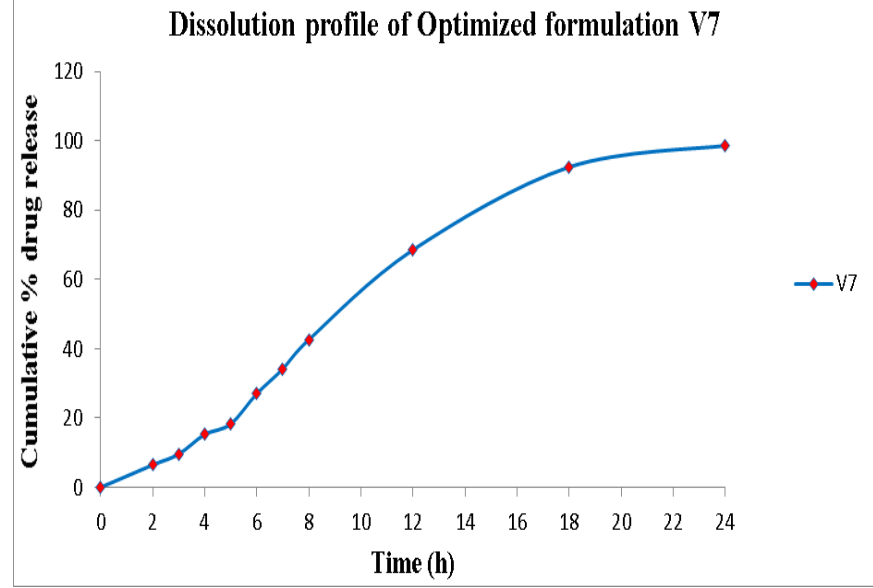

Fig. 17: Dissolution profile of optimized formulation V7

Kinetic modelling and mechanism of drug release Mathematical models play a vital role in the interpretation of mechanism of drug release from a dosage form. It is an important tool to understand the drug release kinetics of a dosage form. The in-vitro drug release profile was applied in different mathematical models i.e. Zero order, First order, Higuchi, Hixsoncrowell and Korsmeyer Peppas and was interpreted in the form of graphical presentation and evaluated by correlation coefficient (r2) represented in Table 19. The following plots were made: Time vs. \% Cumulative drug release (Zero order model); Time vs. Log \% drug remain to be released (First order model), Square root of time vs. \% Cumulative drug release (Higuchi model), Time vs. Cubic root of unreleased fraction of drug(Hixson-crowell model) and log time vs. $\log \%$ cumulative drug release (Korsmeyer peppas model).

\begin{tabular}{cccccc}
\multicolumn{2}{c}{ Table 19: Kinetic modelling of Valsartan } & & & \\
\hline \multirow{2}{*}{$\begin{array}{c}\text { Formulation } \\
\text { code }\end{array}$} & $\begin{array}{c}\text { Zero } \\
\text { order } \\
\text { kinetics }\end{array}$ & $\begin{array}{c}\text { First } \\
\text { order } \\
\text { kinetics }\end{array}$ & $\begin{array}{c}\text { Higuchi } \\
\text { kinetics }\end{array}$ & $\begin{array}{c}\text { Hixson- } \\
\text { Crowell } \\
\text { kinetics }\end{array}$ & $\begin{array}{c}\text { Korsmeyer } \\
\text { Peppas } \\
\text { kinetics }\end{array}$ \\
\cline { 2 - 6 } & $\mathbf{R 2}$ & $\mathbf{R 2}$ & $\mathbf{R 2}$ & $\mathbf{R 2}$ & R2 \\
\hline V1 & 0.9827 & 0.9779 & 0.8853 & 0.9539 & 0.9647 \\
V2 & 0.9730 & 0.9418 & 0.8899 & 0.9718 & 0.9559 \\
V3 & 0.9770 & 0.9728 & 0.8807 & 0.9563 & 0.9714 \\
V4 & 0.9745 & 0.9659 & 0.8800 & 0.9567 & 0.9654 \\
V5 & 0.9768 & 0.9662 & 0.8682 & 0.9698 & 0.9701 \\
V6 & 0.9682 & 0.9606 & 0.8748 & 0.9468 & 0.9642 \\
V7 & 0.9805 & 0.9395 & 0.8929 & 0.9578 & 0.9521 \\
V8 & 0.9759 & 0.9361 & 0.8737 & 0.9702 & 0.9667 \\
V9 & 0.9771 & 0.9730 & 0.8701 & 0.9699 & 0.9755 \\
\hline
\end{tabular}

\section{Zero order model}

\begin{tabular}{cccccccccc}
\multicolumn{10}{c}{ Table 20: In-vitro drug release profile (Time Vs. \% Cumulative drug release) } \\
\hline $\begin{array}{c}\text { Time } \\
\text { (h) }\end{array}$ & $\mathbf{7 1}$ & V2 & V3 & \%4 & V5 & V6 & V7 & V8 & V9 \\
\hline 0 & 0 & 0 & 0 & 0 & 0 & 0 & 0 & 0 & 0 \\
2 & 4.45 & 5.02 & 4.22 & 5.25 & 4.45 & 5.24 & 6.45 & 3.45 & 3.56 \\
3 & 8.34 & 9.56 & 7.23 & 8.64 & 7.54 & 8.02 & 9.56 & 7.55 & 6.28 \\
4 & 10.11 & 12.11 & 10.25 & 11.43 & 10.96 & 12.89 & 15.23 & 9.95 & 9.25 \\
5 & 14.43 & 16.34 & 14.43 & 14.56 & 12.53 & 15.04 & 18.25 & 13.56 & 12.43 \\
6 & 24.21 & 24.5 & 22.58 & 23.41 & 19.96 & 20.48 & 26.95 & 21.11 & 19.55 \\
7 & 32.23 & 34.16 & 30.23 & 30.54 & 29.78 & 32.11 & 34.11 & 28.24 & 26.65 \\
8 & 39.55 & 40.11 & 36.55 & 37.78 & 38.57 & 40.67 & 42.56 & 42.05 & 33.43 \\
12 & 62.45 & 64.78 & 60.44 & 62.65 & 63.98 & 65.43 & 68.45 & 63.45 & 60.23 \\
18 & 82.61 & 83.49 & 82.54 & 86.56 & 85.46 & 88.9 & 92.36 & 78.59 & 75.43 \\
24 & 90.26 & 87.67 & 88.21 & 91.55 & 90.23 & 92.45 & 98.55 & 85.65 & 82.25 \\
\hline
\end{tabular}

First order model

\begin{tabular}{cccccccccc}
\multicolumn{8}{c}{ Table 21: In-vitro drug release profile (Time Vs. Log \% drug remain to be released) } \\
\cline { 2 - 10 } Time & \multicolumn{8}{c}{ Log \% drug remain to be released } \\
\cline { 2 - 10 } (h) & V1 & V2 & V3 & V4 & V5 & V6 & V7 & V8 & V9 \\
\hline 0 & 2.000 & 2.000 & 2.000 & 2.000 & 2.000 & 2.000 & 2.000 & 2.000 & 2.000 \\
2 & 1.980 & 1.978 & 1.981 & 1.977 & 1.980 & 1.977 & 1.971 & 1.985 & 1.984 \\
3 & 1.962 & 1.956 & 1.967 & 1.961 & 1.966 & 1.964 & 1.956 & 1.966 & 1.972 \\
4 & 1.954 & 1.944 & 1.953 & 1.947 & 1.950 & 1.940 & 1.928 & 1.954 & 1.958 \\
5 & 1.932 & 1.923 & 1.932 & 1.932 & 1.942 & 1.929 & 1.912 & 1.937 & 1.942 \\
6 & 1.880 & 1.878 & 1.889 & 1.884 & 1.903 & 1.900 & 1.864 & 1.897 & 1.906 \\
7 & 1.831 & 1.818 & 1.844 & 1.842 & 1.846 & 1.832 & 1.819 & 1.856 & 1.865 \\
8 & 1.781 & 1.777 & 1.802 & 1.794 & 1.788 & 1.773 & 1.759 & 1.763 & 1.823 \\
12 & 1.575 & 1.547 & 1.597 & 1.572 & 1.557 & 1.539 & 1.499 & 1.563 & 1.600 \\
18 & 1.240 & 1.218 & 1.242 & 1.128 & 1.163 & 1.045 & 0.926 & 1.331 & 1.390 \\
24 & 0.989 & 1.091 & 1.072 & 0.927 & 0.990 & 0.878 & 0.785 & 1.157 & 1.249 \\
\hline
\end{tabular}

\section{Higuchi model}

\begin{tabular}{cccccccccc} 
Table 22: In-vitro drug release profile (Square root of time Vs. \% Cumulative drug release) \\
\hline & \multicolumn{10}{c}{$\begin{array}{c}\text { Square root } \\
\text { of time }\end{array}$} & V1 & V2 & V3 & \%4 & V5 & V6 & V7 & V8 & V9 \\
\hline 0.000 & 0 & 0 & 0 & 0 & 0 & 0 & 0 & 0 & 0 \\
1.414 & 4.45 & 5.02 & 4.22 & 5.25 & 4.45 & 5.24 & 6.45 & 3.45 & 3.56 \\
1.732 & 8.34 & 9.56 & 7.23 & 8.64 & 7.54 & 8.02 & 9.56 & 7.55 & 6.28 \\
2.000 & 10.11 & 12.11 & 10.25 & 11.43 & 10.96 & 12.89 & 15.23 & 9.95 & 9.25 \\
2.236 & 14.43 & 16.34 & 14.43 & 14.56 & 12.53 & 15.04 & 18.25 & 13.56 & 12.43 \\
2.449 & 24.21 & 24.5 & 22.58 & 23.41 & 19.96 & 20.48 & 26.95 & 21.11 & 19.55 \\
2.646 & 32.23 & 34.16 & 30.23 & 30.54 & 29.78 & 32.11 & 34.11 & 28.24 & 26.65 \\
2.828 & 39.55 & 40.11 & 36.55 & 37.78 & 38.57 & 40.67 & 42.56 & 42.05 & 33.43 \\
3.464 & 62.45 & 64.78 & 60.44 & 62.65 & 63.98 & 65.43 & 68.45 & 63.45 & 60.23 \\
4.243 & 82.61 & 83.49 & 82.54 & 86.56 & 85.46 & 88.9 & 92.36 & 78.59 & 75.43 \\
4.899 & 90.26 & 87.67 & 88.21 & 91.55 & 90.23 & 92.45 & 98.55 & 85.65 & 82.25 \\
\hline
\end{tabular}


Chandani Makvana et al. / Formulation and Evaluation of Controlled Release Maintenance Dose Loaded.

\section{Hixon crowell model}

\begin{tabular}{ccccccccccc}
\multicolumn{1}{c}{ Table 23: In-vitro drug release profile (Time Vs. Cubic root of unreleased fraction of drug) } \\
$\begin{array}{c}\text { Time } \\
\text { Time }\end{array}$ & $\mathbf{8}$ Cubic root of unreleased fraction of drug \\
\cline { 2 - 11 } & V1 & V2 & V3 & V4 & V5 & V6 & V7 & V8 & V9 \\
\hline 0 & 0.000 & 0.000 & 0.000 & 0.000 & 0.000 & 0.000 & 0.000 & 0.000 & 0.000 \\
2 & 0.070 & 0.079 & 0.067 & 0.083 & 0.070 & 0.083 & 0.102 & 0.054 & 0.056 \\
3 & 0.133 & 0.153 & 0.115 & 0.138 & 0.120 & 0.128 & 0.153 & 0.120 & 0.100 \\
4 & 0.162 & 0.196 & 0.165 & 0.184 & 0.177 & 0.209 & 0.249 & 0.160 & 0.148 \\
5 & 0.235 & 0.268 & 0.235 & 0.238 & 0.203 & 0.246 & 0.302 & 0.220 & 0.201 \\
6 & 0.410 & 0.415 & 0.380 & 0.395 & 0.332 & 0.342 & 0.462 & 0.353 & 0.325 \\
7 & 0.565 & 0.604 & 0.525 & 0.531 & 0.516 & 0.563 & 0.603 & 0.486 & 0.456 \\
8 & 0.717 & 0.73 & 0.653 & 0.679 & 0.696 & 0.742 & 0.784 & 0.772 & 0.589 \\
12 & 1.293 & 1.364 & 1.235 & 1.299 & 1.339 & 1.384 & 1.482 & 1.323 & 1.229 \\
18 & 2.051 & 2.096 & 2.048 & 2.264 & 2.201 & 2.411 & 2.572 & 1.865 & 1.735 \\
24 & 2.506 & 2.332 & 2.366 & 2.605 & 2.504 & 2.680 & 2.856 & 2.212 & 2.033 \\
\hline
\end{tabular}

\section{Korsmeyer peppas model}

\begin{tabular}{|c|c|c|c|c|c|c|c|c|c|}
\hline \multirow{2}{*}{$\begin{array}{l}\text { Log } \\
\text { time }\end{array}$} & \multicolumn{9}{|c|}{ Log $\%$ cumulative drug release } \\
\hline & V1 & V2 & V3 & V4 & V5 & V6 & V7 & V8 & V9 \\
\hline 0.000 & 0.000 & 0.000 & 0.000 & 0.000 & 0.000 & 0.000 & 0.000 & 0.000 & 0.000 \\
\hline 0.301 & 0.648 & 0.701 & 0.625 & 0.720 & 0.648 & 0.719 & 0.810 & 0.538 & 0.551 \\
\hline 0.477 & 0.921 & 0.980 & 0.859 & 0.937 & 0.877 & 0.904 & 0.980 & 0.878 & 0.798 \\
\hline 0.602 & 1.005 & 1.083 & 1.011 & 1.058 & 1.040 & 1.110 & 1.183 & 0.998 & 0.966 \\
\hline 0.699 & 1.159 & 1.213 & 1.159 & 1.163 & 1.098 & 1.177 & 1.261 & 1.132 & 1.094 \\
\hline 0.778 & 1.384 & 1.389 & 1.354 & 1.369 & 1.300 & 1.311 & 1.431 & 1.324 & 1.291 \\
\hline 0.845 & 1.508 & 1.534 & 1.480 & 1.485 & 1.474 & 1.507 & 1.533 & 1.451 & 1.426 \\
\hline 0.903 & 1.597 & 1.603 & 1.563 & 1.577 & 1.586 & 1.609 & 1.629 & 1.624 & 1.524 \\
\hline 1.079 & 1.796 & 1.811 & 1.781 & 1.797 & 1.806 & 1.816 & 1.835 & 1.802 & 1.780 \\
\hline 1.255 & 1.917 & 1.922 & 1.917 & 1.937 & 1.932 & 1.949 & 1.965 & 1.895 & 1.878 \\
\hline 1.380 & 1.955 & 1.943 & 1.946 & 1.962 & 1.955 & 1.966 & 1.994 & 1.933 & 1.915 \\
\hline
\end{tabular}

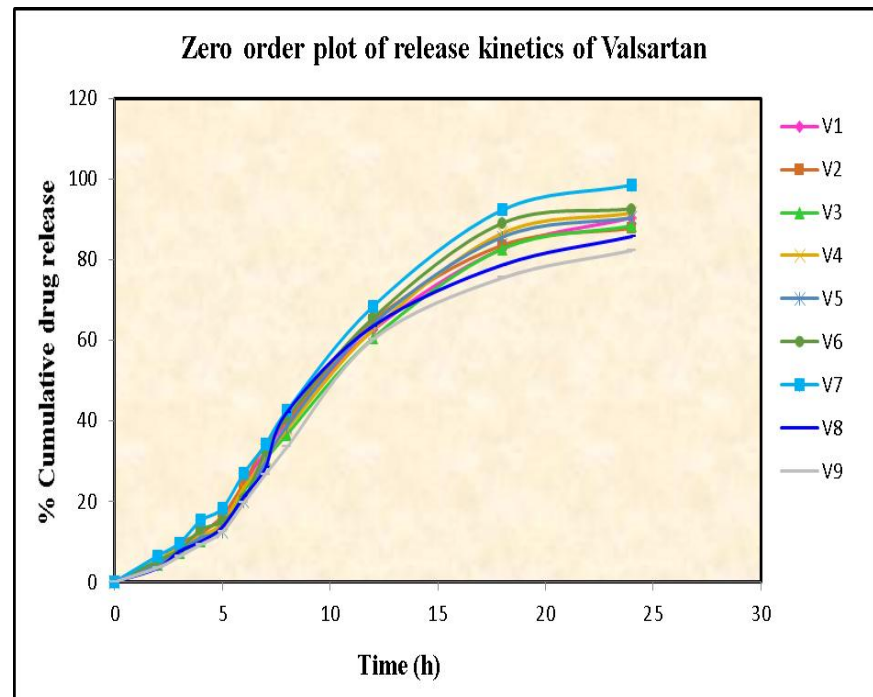

Fig. 18: Zero order plot of release kinetics of Valsartan from Niosomes

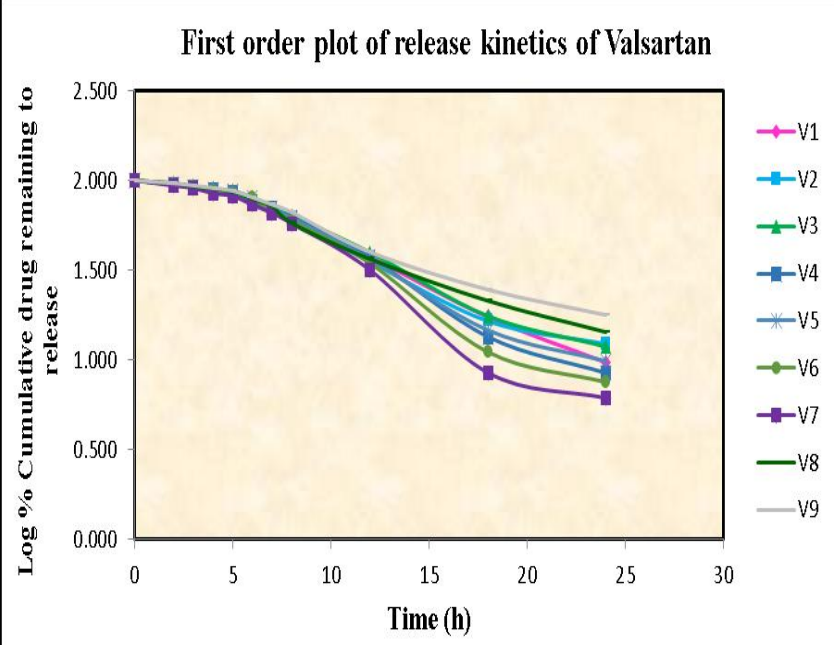

Fig. 19: First order plot of release kinetics of Valsartan from Niosomes

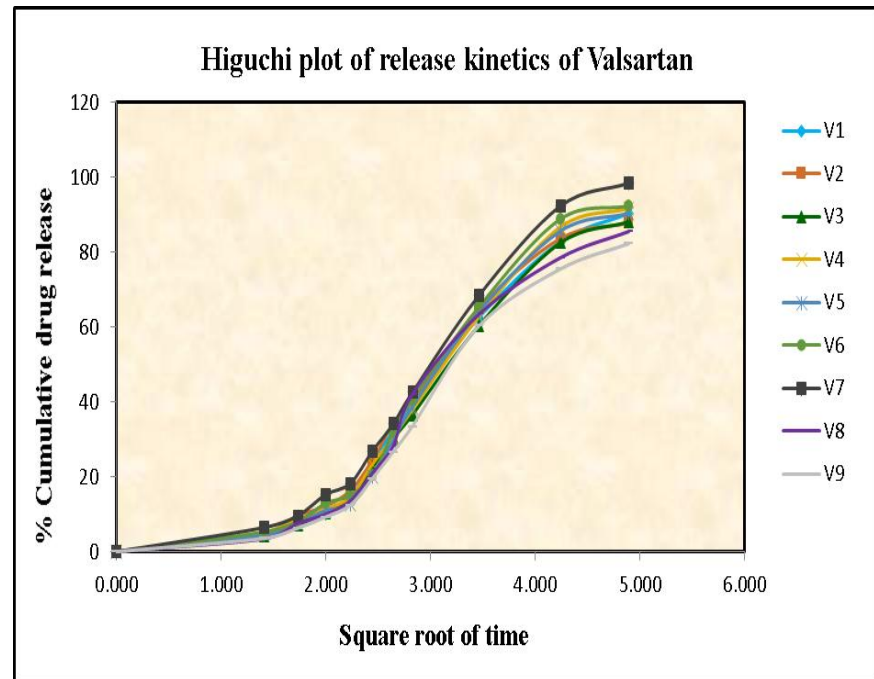

Fig. 20: Higuchi plot of release kinetics of Valsartan from Niosomes

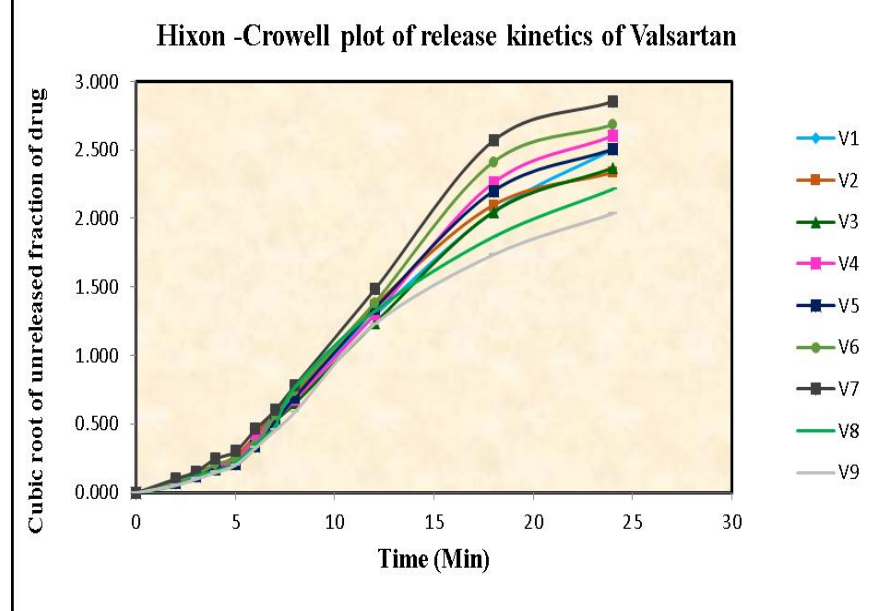

Fig. 21: Hixon crowell plot of release kinetics of Valsartan from Niosomes

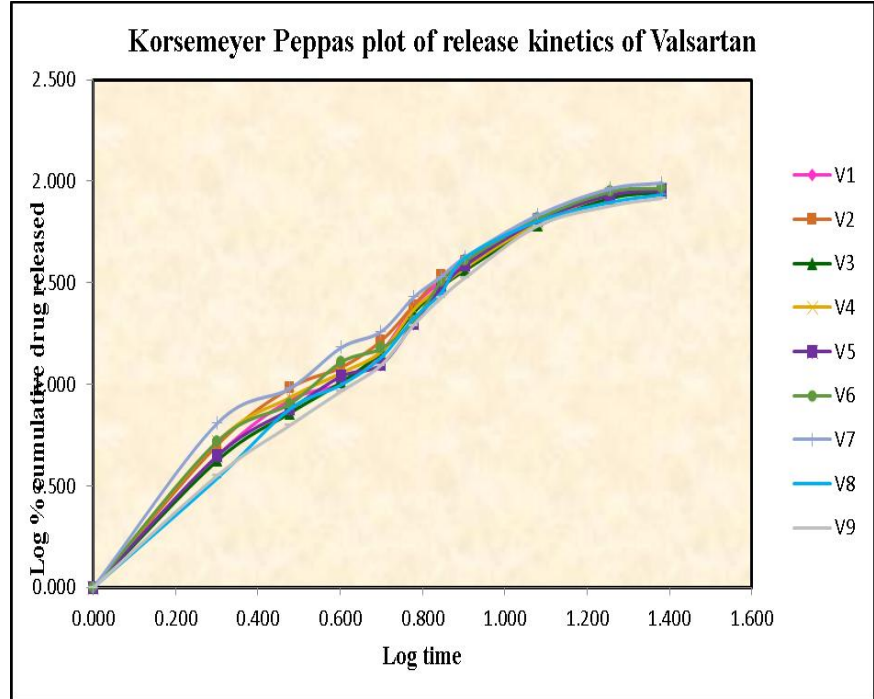

Fig. 22: Korsmeyer peppas plot of release kinetics of Valsartan from Niosomes

\section{Inference}

From the above comparison, it was found that Zero order model showed higher degree of correlation coefficient $\left(\mathrm{r}^{2}\right) \quad 0.9805$ for optimized formulation V7 than other models which indicates that the process of constant drug release from dosage form. Hence, the release of drug is in controlled manner. 


\section{ACKNOWLEDGEMENT}

The author expresses their gratitude to Torrent research centre, Ahmedabad, India for Gift sample of pure drug.

\section{REFERENCES}

1. Arora $\mathrm{R}$, Sharma A. Release studies of ketoprofen niosome formulation. J Chem Pharm Res 2010;2(1):79-82.

2. Sharma SK, Chauhan M, Anilkumar N. Span-60 niosomal oral suspension of fluconazole: Formulation and in vitro evaluation. JPRHC 2009;1:142-56.

3. Pranshu T, Shaffi K. Niosomes: Formulation and Evaluation. Int J Biopharm, 2011; 2(1): 47-53.

4. Rogerson A, Cummings J, Willmott N, Florence AT. The distribution of doxorubicin in mice following administration in niosomes. J Pharm Pharmacol 1998;40:337-42.

5. Baillie AJ, Coombs GH, Dolan TF, Laurie J. Non-ionic surfactant vesicles, niosomes as delivery system for the antileishmanial drug sodium stribogluconate. J Pharm Pharmacol 1986;38:502-5.

6. Chauhan S, Luorence MJ. The Preparation of polyoxyethylene containing non-ionic surfactant vesicles. J Pharm Pharmacol 1989;41:6-10.

7. Blazek-Welsh AI, Rhodes DG. SEM imaging predicts quality of niosomes from maltodextrin-based proniosomes. Pharm Res 2001;18:656-61.

8. Nair AS, Vidhya KM, Saranya TR, Sreelakshy KR, Nair SC. Emulsomes: A novel liposomal formulation for sustained drug delivery. IRJPAS 2013;3:192-6.

9. Naresh RA Raja, GK Pillai, N Udupa, G Chandrashekar. Anti-inflammatory activity of niosome encapsulated diclofenac sodium in arthritic rats. Indian J Pharmacol 1994;26(1):46-8.
10. Khandare JN, Madhavi G, Tamhankar BM. Niosomes novel drug delivery system. The Eastern Pharmacist 1994;37:61-4.

11. Hunter CA, Dolan TF, Coombs GH, Baillie AJ. Vesicular systems (Niosomes and liposomes) for delivery of sodium stibogluconate in experimental murine visceral leishmaniasis. J Pharm Pharmacol 1988;40:161-5.

12. Malhotra $M$, Jain NK. Niosomes as drug carriers. Indian Drugs 1994;31:81-6.

13. Anil A, Thomas L, Sudheer P. Liquisolid compacts: An innovative approach for dissolution enhancement. International Journal of Pharmacy and Pharmaceutical Sciences 2018;10:11-7.

14. Prasanthi S, Vidhyavathi M. Formulation and optimization of buoyant in-situ gelling system of Valsartan using natural polymer. IJPPS 2017;10:128-36.

15. https://www.drugbank.ca/drugs/DB00177

16. Indian Pharmacopoeia: Government of India Ministry of Health and Family Welfare. The Controller of Publications Delhi;2007.p.550,746.

17. Remington, Lippincott, Williams, Wilkins. The science and practice of pharmacy. 20th ed. Wolter kluwer company; 2002.p.691-3.

18. Cooper J, Gun C. Powder Flow and Compaction. Inc Carter SJ ed. Tutorial Pharmacy, New Delhi, hidix CBS Publishers and Distributors;1986.p.211-33.

19. Lachman L, Liberman HA, Kanig JL. The Theory and Practice of industrial Pharmacy. 3rd ed. Varghese Publishing House, Bombay;1987.p.297-300.

20. Klaus Florey: Analytical profiles of drug substances. 64th ed. Elsevier Academic press; 2005.p.327-44.

21. https://www.fda.gov>drugs>ucm 286595

22. https://www.accessdata.fda.gov>appletter

23. Punitha S, Sravanthi C, Tananki G. Evaluation of Aceclofenac Niosomes Prepared By Various Techniques. IJPSRR 2012;16:75- 8 .

HOW TO CITE THIS ARTICLE: Makvana C, Sahoo S. Formulation and Evaluation of Controlled Release Maintenance Dose Loaded Niosomes of Anti-Hypertensive Drug. Int. J. Pharm. Sci. Drug Res. 2019; 11(6): 305317. DOI: 10.25004/IJPSDR.2019.110605 